
$\begin{array}{llllllllllllll} & \text { A } & \text { A } & \text { T } & \text { E } & \text { R } & \text { I } & \text { A } & \text { L } & \text { S }\end{array}$
$\begin{array}{lllllllllllll}P & O & L & E & M & I & C & S\end{array}$
Kwartalnik Historyczny
Vol. CXXVIII, 2021
Eng.-Language Edition no. 5, pp. 167-198
PL ISSN 0023-5903

\author{
KATARZYNA PĘKACKA-FALKOWSKA \\ https://orcid.org/0000-0003-2068-7957 \\ Poznań University of Medical Sciences
}

\title{
THE ENGLISH CONNECTION: JACOB AND JOHANN PHILIPP BREYNE, JAMES PETIVER AND PLANTS: THE CORRESPONDENCE BETWEEN THE BREYNES AND PETIVER FROM THE 1690s*
}

\begin{abstract}
The article discusses the hitherto unknown correspondence between the Danzig (present-day Gdańsk) botanist Jacob Breyne, his son Johann Philipp Breyne, and James Petiver in the last decade of the seventeenth century. Their correspondence documents contacts between one of the most important naturalists of the Polish-Lithuanian Commonwealth in the second half of the seventeenth century and members of the Royal Society. The content of the letters reveals how books, naturalia and various artefacts circulated between Western and East-Central Europe. It also reveals the principles of reciprocity and friendship followed by those who conducted inquiries into natural history. Keyw ords: history of science, transfer of knowledge, Polish Prussia (in the seventeenth century), Danzig/Gdańsk, Royal Society.
\end{abstract}

Jacob Breyne, a 'grand amateur des fleurs', ${ }^{1}$ as his contemporaries called him, died at the age of sixty on 25 January 1697 in Danzig (present-day Gdańsk). ${ }^{2}$ Towards the end of his life his health was deteriorating. There were whole weeks when attacks of gout prevented him from writing ${ }^{3}$

* The author's research in London was made possible thanks to a scholarship from the Lanckoroński Foundation; and in Gotha thanks to the Herzog-Ernst-Stipendien der Fritz Thyssen Stiftung.

${ }^{1}$ Letter by Johann Peter Thomas Walisser to Jacob Breyne, 8 November 1664 , Forschungsbibliothek Gotha (hereafter FB Gotha), Chart. A 790, fol. 126a.

2 'Vita Iacobi Breynii, Botanici Celeberrimi', Das gelahrte Preussen oder monathlicher Außzug aus neuen und alten, gedruckten und ungedruckten, großen und kleinen preussischen Schrifften, 2, 1723, 6, pp. 385-93 (p. 391).

${ }^{3}$ Joannes Philippus Breynius, filius Jacobi: Letters to J. Petiver, British Library (hereafter BL), Sloane Ms 3321, fol.125b. 
and - even more so - botanizing. ${ }^{4}$ His earthly remains were ceremonially laid to rest in Gdańsk's Holy Trinity Church, where the first tomb of the Breyne family was located. ${ }^{5}$ Jacob's botanical work was continued by his youngest son Johann Philipp, who expanded his father's universal collection, that is the musaeum Breynianum.

Jacob Breyne was undoubtedly one of the most important naturalists in the Polish-Lithuanian Commonwealth of the seventeenth century. A private scholar, Breyne was involved in numerous networks of botanici celeberrimi et curiosissimi, networks governed by a unique set of principles of collaboration, reciprocity and friendship. As Henry Oldenburg observed in a letter to Johannes Hewelcke from 1662/63,

friendship among learned men is a great aid to the investigation and elucidation of the truth; if such friendship could be spread through the whole world of learning, and established among those whose minds are unfettered and above partisan zeal, because of their devotion to truth and human welfare, philosophy would be raised to its greatest heights. ${ }^{6}$

This rule was important especially in the case of the studiosi rerum naturalium, above all botanists, who had enjoyed extended networks of correspondence and exchange since the times of Rembert Dodoens (1517-85). ${ }^{7}$

4 'Dr Jacobus Breynius: Letter to J. Petiver: n.d.' [probably 5 November 1692], BL, Sloane Ms 4066, fol. 271b.

${ }^{5}$ Karolina Targosz writes that we do not know where Jacob Breyne was buried (eadem, Jacob Breynius 1637-1697: 'Botanicus celeberrimus' w wymiarze europejskim, Cracow, 2010, p. 67). Yet we do know that Jacob Breyne's body was laid to rest in the Church of the Holy Trinity under gravestone no. 182. 'Księgi grobowe, XVII-XVIII w. Św. Trójca, Św. Anna', Archiwum Państwowe w Gdańsku - State Archives in Gdańsk (hereafter APG), no. 357/83, fol. 85. In the eighteenth century the family tomb was transferred to St Mary's Church, where the botanist's youngest son, Johann Philipp, bought, on 26 April 1718, plot no. 395 ('Neues Stein- oder Leichenbuch, 1695-1840', APG, no. 354/347, fol. 395). The Breyne tombstone in St Mary's Church has been preserved to this day in a good condition.

6 'Magnum quippe momentum ad veritatem indagandam eruendamque affert Ingeniorum contesseratio; quae si per Orbem eruditum universum posset obtineri, atque eos inter institui, qui mentem gerant exauthoratam, partiumque studio superiorem, nec nisi Veritati et hominum commodis addictam, in summum profecto culmen eluctaretur Philosophia', The Correspondence of Henry Oldenburg, 13 vols, ed. and transl. A. Rupert Hall and Marie Boas Hall, Wisconsin, WI, 1965-86, vol. 2: 1663-1665, 1966, p. 26.

${ }^{7}$ Brian W. Ogilvie, The Science of Describing: Natural History in Renaissance Europe, Chicago, 2006, p. 53. For more on the subject, see Wissen im Netz: Botanik und Pflanzentransfer in europäischen Korrespondenznetzen des 18. Jahrhunderts, ed. Regina Hauser et al., Berlin, 2008. 
As Brian Ogilvie observes, collaboration between botanists in the seventeenth century, given the nature of res herbaria, was not only a social fact, but above all a scholarly necessity. It assumed a variety of forms, including multifaceted written work (including translation and editing) in which scholars' own research was complemented by studies of both contemporary authors and those from the past, and was otherwise enriched by joint botanizing, 'field trips' (that is herborizing walks and excursions) and constant exchange of natural objects, books, letters, sundry artefacts and so on. Nor was this collaboration without meetings and discussions in cafes, libraries, gardens and the study-rooms of the virtuosi. In order to become a naturalist and thus a member of the community of nature lovers, an individual also had to accept the ethos of this community. That ethos was characterized by dedication to nature studies, familiarity with works of the classics, participation in various networks of exchange (both material and immaterial exchange) as well as the ability to use a wide range of 'dispositions' typical of natural history as a scholarly discipline and social practice (these included the ability to read and write in Latin, to collect, process and classify natural objects, as well as knowledge of the rules of observatio, of making exsiccata, of cultivating plantae exoticae and so on). Yet, botany was neither a profession, like medicine, nor a trade, nor a type of gainful employment like gardening or horticulture. A lover of res botanica had to be a studiosus: a learned individual with appropriate (material, social, cultural, intellectual and so on) capital, one who in his investigations and social relations was characterized by passion and zeal. ${ }^{8}$

In the case of Jacob Breyne, historians know the most about his published oeuvre, ${ }^{9}$ whereas the manuscripts associated with him have been little explored..$^{10}$ Jacob Breyne's surviving, fragmented hand-written

${ }^{8}$ Ogilvie, The Science of Describing, pp. 54-58.

9 See for example Targosz, Jacob Breynius, passim; Alicja Kurkowa, Jakub i Jan Filip Breynowie: studium z dziejów kultury książki XVII i XVIII wieku, Wrocław, 1989; Johann Gottlieb Bujack, 'Über preußische Naturforscher des 16ten, 17ten und 18ten Jahrhunderts: Bibliografischßliterärische Skizzen: Die Danziger Jacob Breyn, Johann Philipp Breyn und Jacob Theodor Klein', Preußische Provinzial-Blätter, 23, 1840, pp. 193-209, 344-59.

${ }^{10}$ The exception are studies analysing Breyne's horti sicci. For more on the subject, see Simon Jan van Ooststroom, 'Een 17de eeuwsch herbarium uit de omgeving van Danzig', in GedenkboekJ. Valckenier Suringar: 24 december 1864-17 october 1932: gewijd aan de nagedachtenis van prof. dr.J. Valkenier Suringar, leeraar aan de voormalige Rijks hoogere land-, tuin- en boschbouwschool en hoogleraar aan de Landbouwhoogeschool te Wageningen van 1 april 1899 tot $1 \mathrm{ja}$ nuari 1925, ed. J. Jaswiet, Wageningen, 1942, pp. 208-17; Alette Fleischer, 'Gardening Nature, Gardening Knowledge: The Parallel Activities of Stabilizing Knowledge and Gardens in the Early Modern Period', in Gardens, Knowledge and the Sciences in the Early Modern Period, ed. Hubertus Fischer, Volker R. Remmert and Joachim Wolschke-Bulmahn, Basel, 2016, pp. 289-304 (pp. 294-96); eadem, ‘Breyne's Botany: (Re-)locating Nature and Knowledge in 
legacy encompasses, in addition to a limited number of notes from his work on successive publications, ${ }^{11}$ letters to and from correspondents from the Netherlands, the Dutch East Indies, Polish Prussia, France, Italy, England and other countries. The correspondents of the Gdańsk scholar included members of his family, like the Amsterdam collector, merchant and druggist Joan Brayne, ${ }^{12}$ from whom he received curious specimens of fauna and flora for his musaeum Breynianum, ${ }^{13}$ and famous botanists and physicians like Frederik Ruysch (1638-1731), Paolo Boccone (1633-1704), Caspar Commelin (1668-1731), Willem Ten Rhyne (1647-1700) and Johann Georg Volckamer (1616-93), with whom the Gdańsk scholar exchanged books and various plants. ${ }^{14}$

One of the virtuosi who corresponded with Jacob Breyne was James Petiver (1665-1718), a London apothecary, collector, protégé of Hans Sloane (1660-1753) and fellow of the Royal Society. ${ }^{15}$ Although some

Danzig (circa 1660-1730)', in Locations of Knowledge in Dutch Contexts, ed. Fokko Jan Dijksterhuis, Andreas Weber and Huib J.Zuidervaart, Leiden, 2019,pp.107-35 (pp.116-21), 〈https://doi.org/10.1163/9789004264885〉; Katarzyna Pękacka-Falkowska, 'Horti sicci Jacoba Breyne'a z 1659 i 1673 roku', ZH, 83, 2018, 2, pp. 47-83, < http://dx.doi.org/10 .15762/ZH.2018.23 >; Marco de Jong et al.,'The Book Herbaria of Jacob Breyne (1637-1697) in the Collection of Naturalis Biodiversity Center (Leiden, the Netherlands)', Taxon, 2021, ahead of print, 〈https://doi.org/10.21203/rs.3.rs-885416/v1〉.

${ }^{11}$ See for example 'Breyne Jacob: Materialen für die Veröffentlichung von Exoticarum aliarumque minus cognitarum plantarum centuria prima etc. Hschr.', FB Gotha, Chart. A 786.

${ }^{12}$ Joan Brayne's letter to Jacob Breyne, 25 April 1692, FB Gotha, Chart. A 790, fol. $33 \mathrm{a}-33 \mathrm{~b}$. See also the auction catalogue of Joan Brayne's collection preserved in the BL, no. 1044.a.28(2): Catalogus van een Groote Party Extraordinare Curieuse Rariteyten, nagelaten by wijlen Joan Brayne, in sijn leven vermaart Drogist in Amsterdam. Zande by de Overledene in lankheyt van Jaren by malkander en vergadert. Bestaande in veelongemeene Rare en Curieuse Stukken, naderaan de omstaandenzydeuyt gedrukt. Amsterdam (by Abraham Schuurman).

${ }^{13}$ See for example Georg Seger, 'Obs. CXXIIX: De Capreae Moschiferae Exuviis', Miscellanea Curiosa, 1, 1675/1676, 6/7, pp. 169-71; idem, 'Obs. CXXIX: Nuce Indica sive cocco minima cercopitheci faciem representante', Miscellanea Curiosa, 1, 1675/1676, 6/7, pp.172-73. See also the catalogue of natural specimens of the Breyne family compiled after the death of Johann Philipp Breyne: Verzeichniß des von seel. Herrn Doct. Johann Philipp Brayne nachgelassenen berühmten Naturalien Cabinets welches in Danzig in der Langgasse für baares Danziger Geld den... 1765. an den Meistbiethenden soll verkaufet werden, Danzig, 1765.

${ }^{14}$ See for example ‘Reliquiae Jacobi Breynii. Fasciculus III', FB Gotha, Chart. A 790, passim; 'Jakob Breyne an [Brief an Johann Georg Volckamer]: vom 27.02.1683: mit Siegel', Universitätsbibliothek Erlangen-Nürnberg, Bibliothek Trew, no. H62/[1]; 'Johann Georg Volckammer an [Brief an Jakob Breyn]: vom 14.05.1687: mit vorhergehendem durchgestrichenen Brief an Johann Schmiedt', Universitätsbibliothek Erlangen-Nürnberg, Bibliothek Trew, no. H62/[35].

${ }^{15}$ For more on him, see for example Raymond Phineas Stearns, 'James Petiver: 
scholars have claimed that 'it is impossible to [...] find any traces of contacts between [Jacob Breyne] and [...] James Petiver' ${ }^{16}$ evidence of closeness between the two botanists has been preserved in the British Library and the Natural History Museum in London. The correspondence between the two naturalists was mentioned in the 1950s by James Edgar Dandy, who cited short fragments preserved in handwritten drafts; he also pointed to numerous exsiccata given by Jacob Breyne to Petiver and incorporated into the naturalistic collection of the latter. ${ }^{17}$ Dandy's findings were later used by Dutch scholars interested in Breyne's herbaria. ${ }^{18}$ However, probably because of the nature of Petiver's handwriting small and barely legible - along with the format of the sources and the poor state of the paper and its faded ink, ${ }^{19}$ no one since Dandy had decided to go directly ad fontes, with researchers citing instead only fragments of the correspondence included in Dandy's publication. Yet the surviving correspondence between Breyne and Petiver (together with lists of plants and other naturalia both scholars desired or sent to each other, as well as existing exsiccata from the collection of London's Natural History Museum $)^{20}$ show us how knowledge of nature was transferred between England and the biggest city in Polish Prussia in the last decade of the seventeenth century. It should be noted here that from the

Promoter of Natural Science, C. 1663-1718', Proceedings of American Antiquarian Society, 62,1952 , pp. 243-365, as well as the special issue Notes and Records: The Royal Society Journal of the History of Science, 74, 2020, 2, devoted to the life and collecting activities of Petiver.

${ }^{16}$ Targosz, Jacob Breynius, p. 63.

${ }^{17}$ For more on the subject, see The Sloane Herbarium: An Annotated List of the Horti Sicci Composing It; With Biographical Details of the Principal Contributors, Based on Records Compiled by the Late James Britten. With an Introd. by S. Savage, ed. James Edgar Dandy, London, 1958, passim; James Delbourgo, Collecting the World: The Life and Curiosity of Hans Sloane, London 2017, Chapt. 5, pp. 289-90, note 7 [e-book, epub format]; Arnold Hunt, 'Under Sloane's Shadow: The Archive of James Petiver', in Archival Afterlives Life, Death, and Knowledge-Making in Early Modern British Scientific and Medical Archives, ed. Vera Keller, Anna Marie Roos and Elizabeth Yale, Leiden, 2018, pp. 194-221 (p. 195); Richard Coulton, "'What He Hath Gather'd Together Shall Not Be Lost”: Remembering James Petiver', Notes and Records: The Royal Society Journal of the History of Science, 74, 2020, 2, pp. 189-211. The collection after Petiver's death was purchased by Hans Sloane for 4,000 pounds and enriched his vast musaeum. The auction took place on 26 April 1718.

${ }^{18}$ Fleischer, 'Gardening Nature', pp. 293-96.

${ }^{19}$ This is how Dandy characterized the material substratum of J. Petiver's letters to Breyne junior (The Sloane Herbarium, p. 98).

${ }^{20}$ More on these plants, see Katarzyna Pękacka-Falkowska, 'The English connection (cz. 2): Jacob Breyne, James Petiver i rośliny: Breyne'owskie exsiccata z kolekcji Jamesa Petivera', in Bariery - możliwości - wyzwania: Środowisko przyrodnicze a człowiek na przestrzeni dziejów, ed. Piotr Oliński and Wojciech Piasek, Toruń, 2022 [forthcoming]. 
very beginning of the existence of the Royal Society, Gdańsk scholars were in regular contact with its fellows and published their articles in Philosophical Transactions. Thus in a letter of 30 March 1666 Oldenburg wrote to Hewelcke that many of the Society's fellows are:

first of all engaged upon natural history, and to that end are busy in seeking out in all parts those things with which Nature enriches different regions, we trust you to add your contribution. For this purpose, you see the annexed queries; we earnestly beg you either to prepare answers to these yourself or to procure them from friends with whom, perhaps, you correspond in Borussia, Poland, Sweden, and Muscovy. ${ }^{21}$

The list encompassed 23 issues, like the salterns in the Crown, the freezing of various fluids, the summer and winter coats of wild animals, the production of potash and so on. It ended with Oldenburg's brief request to Hewelcke to enable Society fellows to enter into correspondence with people from Poland, Sweden, Ukraine and Livonia interested in historia naturalis et philosophia naturae. ${ }^{22}$

Gdańsk citizens who soon became Royal Society correspondents included Michael Behme von Behmenfeld (1616-77) and Johannes Schmiedt vel Fabricius (1623-90), ${ }^{23}$ who were followed by Israel Conradt (16341715) and the English merchant Christopher Kirgby, who was residing in Gdańsk. Whether Jacob Breyne's contacts with the Royal Society were established thanks to Hewelcke or elsewise is hard to say given the lack of relevant sources, although presumably Breyne began his correspondence with Petiver (and through him with other fellows of the Royal Society) thanks to the botanist network he was part of and not thanks to the author of Selenographiae. ${ }^{24}$

21 'Cumque inprimis Historiam Naturalem moliantur, in eumque finem undequaque ea conquirere satagant, quibus Regiones quasque locupletavit Natura, Te quoque symbolam tuam huc collaturam omnino confidimus. Hinc est, quod Erotemata quaedam hic consignata vides; quibus ut responsum vel ipse pares, vel per Amicos, quibuscum forte in Borussia, Polonia, Suecia, Muscovia, commercium colis litterarium, procures, enixe rogamus', The Correspondence of Henry Oldenburg, vol. 3: 1666-1667, 1966, p. 73.

${ }^{22}$ Ibid., pp. 73-75.

${ }^{23}$ Katarzyna Pękacka-Falkowska and Bartłomiej Siek, 'Johannes Schmiedt (16231690)', Journal of Neurology, 2021, ahead of print <https://doi.org/10.1007/s00415-021 $-10602-\mathrm{w}>$.

${ }^{24}$ The thirteen-volume edition of The Oldenburg Correspondence edited by A. Rupert Hall features no information about Breyne and his studies. Jacob Breyne was mentioned by Tancred Robinson in his letters to John Ray (The Correspondence of John Ray: Consisting of Selections from the Philosophical Letters Published by Dr. Derham, and Original Letters of John Ray in the Collection of the British Museum, ed. Edwin Lankester, 
Nor do we know when exactly Jacob Breyne and Petiver began exchanging letters, books and naturalia: live and dried plants, and occasionally preserved animals. The oldest surviving translation into English of a letter by Breyne ${ }^{25}$ to Petiver comes most probably from 5 November 1692 (no. 1). ${ }^{26}$ In this letter the Gdańsk scholar referred to the Englishman's correspondence - which has not survived - from February that year, to which was attached a parcel with wild grass from England, ${ }^{27}$ and to his own letter from October, which has also been lost. In the November letter Breyne praised the botanical work of two renowned English naturalists, John Ray (1627-1705) and Leonard Plukenet (1642-1706), whom he respected greatly, and complained about the scholarly dishonesty of another of his friends, Paul Hermann (1646-95), ${ }^{28}$ as Hermann had failed to observe the rules established among the studiosi rerum naturalium when he used Breyne's botanical findings without indicating their author. He also described his growing health problems, which prevented him from working on the final version of the Prussian-Kashubian Viridarium - a long-awaited but never published study devoted to the local flora of Kashubia

London, 1848, passim). Breyne himself, on the other hand, would send various exsiccata directly to William Sherard. See for example Helichrysum sp. and Althaea sp. preserved in the Sherard Herbarium, Oxford, <https://herbaria.plants.ox.ac.uk/bol/ sherard/Explore $\rangle$ [accessed 15 January 2020]. For more on Breyne's exsiccata in the Oxford collection, see Hermia Newman Clokie, An Account of the Herbaria of the Department of Botany in the University of Oxford, London, 1964, passim.

${ }^{25}$ An analysis of the handwriting suggests that the source was not compiled by Jacob Breyne.

26 'Dr Jacobus Breynius: Letter to J. Petiver: n.d.' [probably 5 November 1692], BL, Sloane Ms 4066, fol. 271a-72b.

${ }^{27}$ Some of them may have later found their way with the Prussian grasses into the hands of Johann Jakob Scheuchzer, author of a monograph on grasses, who received numerous specimens of these plants from Gdańsk and its environs from Breyne junior. See Scheuchzer, Agrostographia sive Graminum, Juncorum, Cyperorum, Cyperoidum, iisque affinium Historia, Zurich, 1719. Jacob Breyne, on the other hand, gave specimens of domestic grasses to Petiver. The surviving specimens of Gr[amen] Mont[anum] Avonaelocullis rubris C [aspar] B [auchinus] Pr[odromos Theatri Botanici] and Gr[amen] Foliolis Junceis rad[icae] jubata C[aspar] B [auchinus], Gr[amen] Foliolis Jucedis crassioribus minus can be found in the Natural History Museum, London (hereafter NHM), Sir Hans Sloane Herbarium (hereafter H.S.), no. 190, fol. 28, 38, 42. The second part of the present study [Pękacka-Falkowska, 'The English connection (cz. 2)'] focuses on an analysis of the specimens given to James Petiver by Jacob and Johann Philipp Breyne, which are currently to be found in the Natural History Museum in London.

${ }^{28}$ The material evidence of their friendship includes a herbarium vivum with plants from the Far East given to Jacob Breyne by Hermann: Stephan Rauschert, 'Das Herbarium von Paul Hermann (1646-1695) in der Forschungsbibliothek Gotha', N.F. Hercynia, 7, 1970, 4, pp. 301-28 〈https://www.zobodat.at/pdf/Hercynia_7_0301-0328.pdf〉 [accessed 15 January 2020]; ‘Herbarium Paul Hermann', FB Gotha, Chart. A 785. 
and Pomerania. ${ }^{29}$ As a member of an extensive rerum naturalium exchange network, he pointed out that he had recently given (and would continue to give) Petiver (via the sea route) ${ }^{30}$ various gifts, primarily books as well as live and dried plants (both indigenous and exotic). In addition, he urged the London apothecary to send him a list of the plantae he would like to receive for his collection, promising that he would try to comply with his requests. Such a list was indeed sent from England to Gdańsk at some unspecified point. It contained the names of over 100 species of European and exotic plants which Petiver wanted to add to his musaeum, and perhaps also his garden (provided that Breyne had their grafts, seedlings or seeds). ${ }^{31}$

The Englishman drafted a reply to the letter of 5 November which had reached London on 18 November - only four weeks later, on Christmas Eve (no. 2, draft). ${ }^{32}$ He warmly thanked the Gdańsk naturalist for sending him some dried plants and several publications, the titles of which cannot be reconstructed owing to gaps in the surviving sources.

${ }^{29}$ For more on the subject, see Katarzyna Pękacka-Falkowska, 'Flora rodzima w badaniach Jacoba Breyne'a', in Kolekcje przyrodnicze i gospodarcze innowacje - tradycja i nowoczesność: Pamięci księżnej Anny z Sapiehów Jabłonowskiej (1728-1800), ed. Iwona Arabas and Robert Księżopolski, Warszawa and Ciechanowiec, 2021, pp. 115-31; eadem, 'Horti sicci'. For more on research into the local flora in the Early Modern Period in German-speaking countries, see for example Alix Cooper, Inventing the Indigenous: Local Knowledge and Natural History in Early Modern Europe, Cambridge, MA, 2008.

${ }^{30}$ From the very beginning of their contacts with the Royal Society fellows the Gdańsk scholars would send them letters, books and other gifts through captains of merchant ships. Less often they would use Gdańsk students on their peregrinationes academicae, merchants or members of their own families as intermediaries. On many occasions Hewelcke mentioned the various channels for sending letters, books and artefacts to England in his correspondence with Oldenburg. For example, he often used the services of John Parker, captain of the English ship Nightingale, as well as captains of other Gdańsk, Swedish or English vessels. The intermediaries transporting naturalia for Petiver and Sloane were often mentioned also by Breyne junior. For more on the methods of exchanging naturalia and books in the Early Modern Period in scholars' networks, see for example Silent Messengers: The Circulation of Material Objects of Knowledge in the Early Modern Low Countries, ed. Sven Dupré and Christoph Lüthy, Münster, 2008.

31 'A Copy of a Catalogue I sent to $\mathrm{M}^{\mathrm{r}}$ Breynius being of sent plants as I should be glad to receive etc.', BL, Sloane MS 3332, fol.147-52. On the circulation of live plants, grafts, seedlings and seeds in Gdańsk, see for example Ewa Barylewska-Szymańska and Wojciech Szymański, 'Gdańskie ogrody drugiej połowy XVIII w. w anonsach prasowych', in Gdańskie ogrody, Gdańsk, 2018, pp. 57-119; Katarzyna Pękacka-Falkowska, 'Johann Philipp Breyne i jego ogrody: hortus vivus i hortus siccus', in Historia - klimat przyroda: Perspektywa antropocentryczna, ed. Piotr Oliński and Wojciech Piasek, Torun, 2018, pp. 217-28; eadem, 'The English connection (cz. 2)'.

32 'Dr Jacobus Breynius: Letter to, from J. Petiver: n.d.', BL, Sloane Ms 4067, fol. $81 a-81 b$. 
He also wrote that he had publicly read Breyne's correspondence in a London cafe, Temple House, at a regular Friday meeting of the local botanists, ${ }^{33}$ who included Plukenet, Sloane, Isaac Newton (1643-1727) and Samuel Doody (1656-1706). He sent the Gdańsk naturalist his own best regards along with greetings from those present at the meeting and informed Breyne of their newly published or planned books, as well as the offices they held. In particular, he stressed the role which Doody could play as the new director of the Apothecaries' Garden in Chelsea, having succeeded John Watts who had been dismissed by his superiors on account of numerous instances of negligence in running the garden. In addition, he praised Sloane not only as the former physician to Christopher Monck (1653-88), 2nd Duke of Albemarle and Governor of Jamaica, but also as a distinguished expert on plants from the West Indies, telling Breyne that his study of Jamaican flora would soon be published. ${ }^{34}$ Finally, he promised to send to Gdańsk new botanical specimens, and asked his colleague from Polish Prussia to send various naturalia to London and so on.

It seems that the correspondence between the naturalists had a hiatus in 1693 . The next surviving letter (no. 3, original) ${ }^{35}$ comes from May 1694 and was written down by Jacob's fourteen-year-old son, Johann Philipp; Jacob had already designated the boy as his successor in botanical research. ${ }^{36}$ As Jacob was unable to hold a pen in his hand due to attacks of gout, 'thus neglecting domestic and overseas correspondence', he decided to dictate the letter to the youngest of his male descendants. Breyne thanked Petiver for his botanical gifts, informing

${ }^{33}$ Margaret Riley, 'The Club at the Temple Coffee House Revisited', Archives of Natural History, 33, 2006, 1, pp. 90-100; Stearns, 'James Petiver', p. 253.

${ }^{34}$ Sloane's first publication, on the Jamaican flora, was the Catalogus plantarum quae in insula Jamaica sponte proveniunt, vel vulgo coluntur, cum earundem synonymis \& locisnatalibus; adjectis aliis quibusdam quae in insulis Maderae, Barbados, Nieves, \& Sancti Christophori nascuntur. Seu prodromi historiae naturalis Jamaicae pars prima. Autore Hans Sloane, London, 1696. It was followed by the two-volume A voyage to the islands Madera, Barbados, Nieves, S. Christophers and Jamaica: with the natural history of the herbs and trees, four-footed beasts, fishes, birds, insects, reptiles, \&c. of the last of those islands; to which is prefix'd, an introduction, wherein is an account of the inhabitants, air, waters, diseases, trade, \&c. of that place, with some relations concerning the neighbouring continent, and islands of America. Illustrated with figures of the things described, which have not been heretofore engraved. In large copper-plates as big as the life, Printed by B.M. for the author, London, 1707(-1725). The books were highly praised by Johann Philipp Breyne.

${ }^{35}$ Joannes Philippus Breynius, filius Jacobi: Letters to J. Petiver, BL, Sloane Ms 3321, fol. $9 \mathrm{a}-13 \mathrm{a}$.

36 'Niederschrift über eine botanische Exkursion Jacob Breynes mit seinem Sohn Johann Philipp “in Cassubia”, 18-20 VI 1692', FB Gotha, Chart. A 788, fol. 47-48. 
him at the same time that he had sent him a small packet with dried Prussian plants through a new sea captain. ${ }^{37}$ In addition, he told him that he would soon send to England more plantae, especially exotic specimens, and commented on the work of various foreign plant lovers and on the progress in the publication of his Viridarium. Interestingly, the letter was partly translated into English by one of Petiver's collaborators and added into the botanist's private archive. ${ }^{38}$ It seems that, like many other Englishmen, Petiver was more familiar with vernacular languages than with Latin, although the apothecary did use this language as well (cf. no. 5). ${ }^{39}$

The last surviving letter (draft) from the correspondence between the botanists is not dated (no. 4). ${ }^{40}$ Worried by a lack of reply to his earlier message, sent most likely in May 1694, Petiver this time addressed his correspondence to Breyne junior, asking about the health of his father. He also promised to continue to exchange naturalia with him, asking in particular for Prussian insects that had attracted his attention and were to be added to his London collection. We need to bear in mind that Western Europe at the time had better access to exotica than to rare botanical specimens from the Baltic region or from Russia. ${ }^{41}$ It seems that the Breynes soon complied with the apothecary's request. After all,

37 Specimens of Kashubian and Prussian plants sent to Petiver have been preserved in the following herbaria: NHM, H.S. no. 148, fol. 80, 250, 253, 268; H.S. no. 149, fol. 100; H.S. no. 231, fol. 88-108 and, on unnumbered leaves, a list of 49 domestic indigenous plants sent from Gdańsk. For more see Pękacka-Falkowska, 'Flora rodzima', pp. 123-25; eadem, 'The English connection (cz. 2)'.

${ }^{38}$ Joannes Philippus Breynius, filius Jacobi: Letters to J. Petiver, BL, Sloane Ms 3321, fol. $125 b-128 b$ (verso pages).

${ }^{39}$ Copy of James Petiver's letter to Johann Philipp Breyne, year 1697, BL, Sloane Ms 3333, fol. 179b. Numerous English scholars relied on the services of various translators from East-Central Europe; suffice it to recall that until the 1680s, Thomas Ramsay (Tomas Ramza), a Calvinist cleric born in Kedainiai, worked with Robert Boyle as a translator of his works into Latin. On the other hand, in his private correspondence with Petiver and Sloane J.P. Breyne fairly quickly decided to abandon Latin and write in English, much to the delight of his addressees. Thus in a letter from Oxford sent to Petiver on 5 October 1702 Breyne wrote: 'Pray excuse my Boldness, that Take to write You in English, I hope You will take it for a sing [sic!] of inclination, that I have for English Tongue' (Joannes Philippus Breynius, filius Jacobi: Letters to J. Petiver, BL, Sloane Ms 3321, fol. 101b-102a).

${ }^{40}$ Joannes Philippus Breynius, filius Jacobi: Letters to J. Petiver, BL, Sloane Ms 3321, fol. 14a.

${ }^{41}$ In the seventeenth and eighteenth centuries such rarities included, in addition to amber, penduline tit nests. For more on the subject, see for example letters by Christian Heinrich Erndtel to Johann Philipp Breyne, FB Gotha, Chart. B 786, fol. 76-77, 85-88; Joannes Philippus Breynius, filius Jacobi: Letters to Sir H. Sloane, BL, Sloane Ms 4045, fol. 117; Joannes Philippus Breynius, filius Jacobi: Letters to Sir H. Sloane, BL, Sloane Ms 4048, fol. 110; Joannes Philippus Breynius, filius Jacobi: Letters to Sir H. Sloane, BL, Sloane Ms 4050, 
among the specimens sent from Gdańsk to London in the late 1690s and mentioned in one of the Centuria of the Museum Petiverianum we find the papillo prutenicus fuscus butterfly as well as information that it was a very rare species appearing in (Polish) Prussia once every seven years, according to Jacob Breyne, 'the most celebrated botanist'. ${ }^{42}$

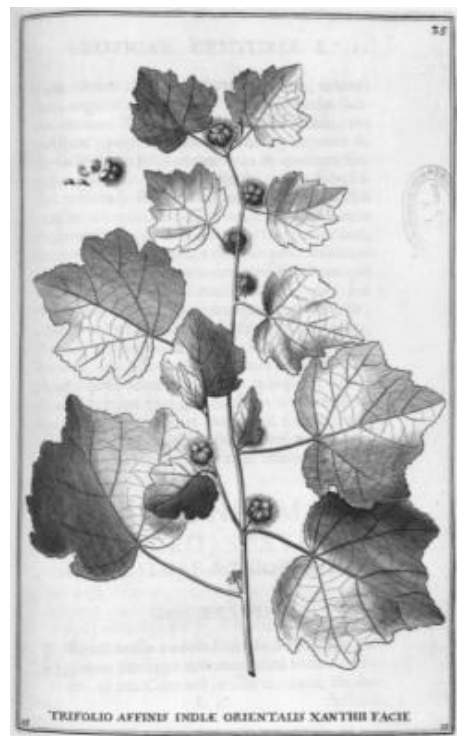

Fig. 1: Engraving from the Centuria showing one of the Indian exsiccata* given by Jacob Breyne to James Petiver.

Source: Jacob Breyne, Exoticarum aliarumque minus cognitarum plantarum centuria prima, cum figuris aeneis summo studio elaboratis, Gdańsk, 1678, insert between pp. 82-83.

${ }^{*}$ A dried object corresponding to the image of the plant from the illustration has been preserved in the Natural History Museum (London), H.S. no. 231, fol. 108.

fol. 90; Katarzyna Pękacka-Falkowska, 'Remizy i uczeni, czyli o ptaszku-rzemieślniku i jego kunsztownych gniazdach', 〈https://www.wilanow-palac.pl/remizy_i_uczeni_ czyli_o_ptaszku_rzemieslniku_i_jego_kunsztownych_gniazdach.html $\rangle$ [accessed 15 January 2020].

${ }^{42}$ Centuria II and III of the Museum Petiverianum (London, 1695-1703) enlisted Japanese plants which the apothecary received from Gdańsk; Centuria VI and VII - plants from Ceylon as well as Prussian insects collected by Breyne. BL, Sloane Ms 3330, fol. 176, 190; Musei Petiveriani Centuria VI et VII: no. 514: 'Papillo Prutenicus fuscus, flexionibus maculisque albis \& aureis, sub tus diversis coloribus variegatus, The septenntal Prussia butterfly. Jacobus Breynius that late most celebrated Botanist sent me this from Prussia, where he says is reported they appear there but once in seven Years.' No. 625: 'Capparis Zeylanica duplicatis spinis folio acuto. This Dr Hermann sent from Zeylon to that incomparable Botanist Jacobus Breynius, from whom I had it.' Cf. 'Jacobus Breynius his Indian etc.', BL, Sloane Ms 3331, fol.39a. 
In the following years Jacob Breyne and Petiver most likely continued to exchange letters, although we have no epistolary evidence that would unequivocally confirm this. However, the continued closeness between the two naturalists was mentioned by Johann Philipp Breyne in the $1700 \mathrm{~s} .{ }^{43}$ The hypothesis is further substantiated by some of the additions to the Museum Petiverianum. For example, a dried sprig of a Japanese cypress was sent to Petiver by his 'late worthy Friend and Patron Jacobus Breynius, from Dantzick a little before his much lamented death' ${ }^{44}$

Significantly, in 1697, the year of Jacob's death, the then seventeen-year-old Johann Philipp began to exchange letters with the thirty-two-year-old Londoner on his own. ${ }^{45}$ The first personal letters exchanged between Petiver and Breyne junior concerned the interrupted correspondence with the latter's father. In addition, Johann Philipp wanted to give to Petiver the naturalia Jacob had promised before his death. And so in the first half of 1697 Petiver received from Johann Philipp thirty-four dried Indian plants previously owned by his father and on 1 May compiled a detailed list of these gifts. The list also contained some information about when and from whom Jacob Breyne had received a given dried flora specimen and where he had written about it, which means that Johann Philipp sent Petiver - like his father before him - exsiccata with additional information. ${ }^{46}$ Another, non-dated list by Petiver encompassed names of thirty-seven Indian plants as well as 'other rare plants' and natural objects sent to England from Gdańsk at some point. The naturalia listed this time included some insects, like the Prussian butterflies phalena argus and papilio Prutenicus. ${ }^{47}$ Some of the plants sent from Polish

${ }^{43}$ James Petiver's letters to Johann Philipp Breyne of 10 April 1706 and 26 June 17.., FB Gotha, Chart. B 787, fol. 482a, 492a.

${ }^{44}$ Musei Petiveriani Centuria II et III: no. 183: 'Cupressus Japonica Arboris Vitae foliis $\&$ facie. Fim-noki Japonensibus sive arbor ignea. This amongst a Collection of very curious plants, was sent me by my late worthy Friend and Patron Jacobus Breynius, from Dantzick, a little before his much lamented death.' The specimen has been preserved in NHM, H.S. no. 331, fol. 94.

${ }^{45}$ Copy of James Petiver's letter to Johann Philipp Breyne, year 1697, BL, Sloane Ms 3333, fol. 178b-80b.

${ }^{46}$ Ibid., 177a-78b. Cf. for example NHM, H.S. no. 176, fol. 2, 3, 30, 23, 24, 38, 41, 42, 45, 46, 48, 75; NHM, H.S. no. 231, fol. 109-13; NHM, H.S. no. 257, passim. Some dried plants obtained from the Breynes were presented publicly at an ordinary meeting of the Royal Society on 6 August 1701: 'Pettiver shewed, cloase dryed samples of Cloves, cinamon, tea trees \& many others had been sent him from Breynius who had rec. them from the East Indies. He was thanked for this favour'. 'Meetings of the Royal Society, 1699-1702', The Library and Archives of the Royal Society (hereafter LARS), no. MS/577, bs.

47 'Jacobus Breynius his Indian etc.', BL, Sloane Ms 3331, fol. 449a-449b. Cf. Copy of James Petiver's letter to Johann Philipp Breyne, year: 1697, BL, Sloane Ms 3333, fol. 178a. 
Prussia to London and mentioned in both of Petiver's lists were - as has already been mentioned - described by Jacob Breyne in his Centuria, Prodromus as well as some reports from Miscellanea Curiosa (Fig. 1) ${ }^{48}$ The London apothecary had all these works in his library, as we can learn from a hand-written catalogue, Bibliotheca Petiveriana Natural[ium] Rerum et Medicina $[e] ;^{49}$ he may have received them from the Gdańsk scholar as part of their friendly exchange of letters, naturalia and books.

It is, therefore, not surprising that the surviving first two drafts of Petiver's letters to Johann Philipp Breyne, sent to Gdańsk after Jacob's death and before his son's departure for the United Provinces to study medicine at Leiden University, provide us with valuable evidence of the friendship between the English apothecary and the deceased Gdańsk botanist (nos. 5-6)..$^{50}$ In his correspondence from 1697 and 1698 Petiver asked Johann Philipp to continue the exchange of botanical specimens begun by his father and to send him information about the Gdańsk plants collected by the late botanicus celeberrimus. The English apothecary wanted, for example, Johann Philipp Breyne to obtain for him Prussian insects and molluscs, as well as a complete list of the domestic (Prussian-Kashubian) exsiccata from the collection of Breyne senior, and then a list - as extensive as possible - of the plantae newly discovered by the author of Prodromus. ${ }^{51}$ Petiver also informed Johann Philipp that

${ }^{48}$ For example, a dried stem of the Alcea fructu lappaceo Zeylandica (NHM, H.S. no. 231. fol. 108) was included in Breyne's Prodromus 1. (Prodromus fasciculi rariorum plantarum, Anno M.DC.LXXIX. in Hortis Celeberrimis Hollandiae, praesertim Incomparabili \& Nobilissimo illo Florae Pandocheo Illustrissimi atq[ue] Excellentissimi Domini, Domini Hieronymi Van Beverningk \&c. \&c. observatarum a Jacobo Breynio, Gedanensi. Cui accedunt Interrogationes de nonnullis Plantarum ab Auctore in Centuria prima descriptarum partibus, quibus, tempore editionis Centuriae primae, Idem ille ut plurimum destitutus fuit, Gdańsk, 1680, p. 2) as Alcea Indiae Orientalis, fructu lappaceo, folio Ribis. Breyne also described it in his Centurii (Exoticarum aliarumque minus cognitarum plantarum centuria prima, Gdańsk, 1678, pp. 82-83, cap. 35) as Trifolium Affinis Indiae Orientalis Xanthii Facie, adding an illustration to his description. A dried flora specimen from India was obtained in the Netherlands in 1672 by Joan Brayne and sent to Gdańsk. The variability of plant names in pre-Linnaean times forces us in any research into the history of botanical classifications to take into account three parallel series of sources: narrative sources, iconographic sources and any surviving exsiccata.

${ }^{49}$ Catalogue of James Petiver's library, BL, Sloane Ms 3337, fol. 35b, 41a. In the catalogue books by Jacob Breyne were classified in the Botanica category. They were Centuria (1678) as well as Prodromus 1. (1680) and 2. (1689). Petiver may also have read Breyne's botanical observationes, as his collection featured numerous issues of Miscellanea Curiosa (ibid., fol. 6a, 33a).

${ }^{50}$ Copy of James Petiver's letter to Johann Philipp Breyne, year 1697, BL, Sloane Ms 3333, fol. 178b-80b.

${ }^{51}$ Petiver additionally explained to Breyne what to do with snail shells before they were to be sent to England. We need to bear in mind that the Englishman prepared 
in 1697 he met in London his elder brother Jacob, ${ }^{52}$ who had travelled there on business, and 'saw in his face the image of the young men's father'. When he learned that Johann Philipp Breyne was planning to study medicine in the Netherlands and then to visit England, he promised also because of the memory of his father - to introduce him into the Royal Society, as he had not managed to do this for his father. ${ }^{53}$ Soon, on 30 July 1701, during an ordinary meeting of the Society, the apothecary presented to its members Johann Philipp's published disputation from Leiden, Dissertatio de radice gin-sem, seu Nisi, et Chrysanthemo bidente Zeylanico Acmella dicto, ${ }^{54}$ which focused on the properties of the acmella in the treatment of kidney and bladder stones. ${ }^{55}$

Indeed, in the summer of 1698 the then twenty-two-year-old Johann Philipp Breyne left Polish Prussia for many years, ${ }^{56}$ beginning his long peregrinatio medica. After a short stay in Amsterdam, on 18 September he

special instructions for people who obtained for him various naturalia, both plants and minerals or animals. Such instructions have been preserved in manuscripts (BL, Sloane Ms 3332, fol. 1a-6b), and in printed form in Museum Petiverianum, the 'Advertisements' section.

${ }^{52}$ Jacob Breyne junior was born on 4 October 1667 and died on 14 June 1718 . He was recorded in the city register as a merchant. Dorothea Weichbrodt-Tiedemann, $\mathrm{Pa}$ trizier, Bürger, Einwohner der Freien und Hansestadt Danzig in Stamm- und Nementafeln vom 14.-18. Jahrhundert, 5 vols, Klausdorf bei Kiel, 1988-93, vol. 1, 1988, p. 96 (Tafel: v. Brayne, Breyne, Brein).

${ }^{53}$ Petiver presented Johann Philipp Breyne's scholarly activity to Royal Society fellows in the summer of 1701, having informed the Gdańsk naturalist of his plans in a letter of 4 June (BL, Sloane Ms 3334, fol.34a-35b). J.P. Breyne was elected Fellow of the Royal Society on 21 April 1703 ('Meetings of the Royal Society, 1702-1707', LARS, no. MS $/ 578$, bs.).

${ }^{54}$ The dissertation was defended by J.P. Breyne on 26 June 1700 during a public dispute presided over by Frederik Dekkers. It was dedicated to Nicolaes Witsen (1641-1717), a famous collector, director of the Dutch East India Company, friend of Tsar Peter I and two-time mayor of Amsterdam.

55 'Meetings of the Royal Society, 1699-1702', LARS, no. MS/577, bs. 'There was an acc $^{t}$ read of the vertues of acmella in breaking $y^{\text {e }}$ stone, it was taken from a dissertation of Breynius. There was in it the history of this medicine'.

${ }^{56}$ Johann Philipp Breyne returned to Polish Prussia on 1 January 1705, initially planning to go back to Amsterdam or London for some time. See for example 'J.P. Breyne. Reisetagebuch 1. Januar 1704 bis 3. Januar 1705’, FB Gotha, Chart. B 968, fol. 141; Joannes Philippus Breynius, filius Jacobi: Letters to J. Petiver, BL, Sloane Ms 3321, fol. 87b-88a: 'For tho' I'm now in My native country, I'm not resolved yet to stay here not for want of Friends but because here is no curious Body about the Natural History and Botany in the whole Tour. Therefore I have / more inclination for Holland or England, if I know to make my Fortune in the last, I would choose to live there, but being a Stranger, I dare not. I am much obliged to you, for your kind invitation and encouragement. I design to stay here all the winter, and then the next spring I might return into Holland'. 
was matriculated at the Academia Lugduno-Batava; ${ }^{57}$ four years later he submitted there a pro gradu dissertation. Breyne's period of study in the Netherlands as well as his visit to England in 1702 began a new stage in his friendship with Petiver. ${ }^{58}$ Jacob Breyne virtually disappeared from their letters from $1700-13,{ }^{59}$ with the two correspondents focusing on their own activities, both scholarly and non-scholarly.

The letters from 1692-98 that Jacob and Johann Philipp Breyne exchanged with Petiver are a valuable source for the study of the history of scholarship in the Polish-Lithuanian Commonwealth, including the collecting practices and transfer of botanical knowledge, as well as the social history of Polish Prussia. This is the oldest surviving hand-written

${ }^{57}$ Album studiosorum Academiae Lugduno Batavae MDLXXV-MDCCCLXXV: accedunt nomina curatorum et professorum per eadem secula, ed. Willem Nikilaas Du Rieu, Hague, 1875 , p. 751.

${ }^{58}$ Johann Philipp Breyne did not come to England as a person with no connections, a person requiring letters of recommendation from renowned Gelehrte facilitating contact with local scholars, although it should be noted that he had received such letters from Caspar Commelin, Frederik Dekkers and Govert Bidloo on the eve of his departure. In 1702 Breyne arrived in England as a friend expected by Petiver, with whom he had corresponded regularly and exchanged books during his studies (see for example Joannes Philippus Breynius, filius Jacobi: Letters to J. Petiver, BL, Sloane Ms 3321, fol. 25a, 53a), and who became his direct patron and introduced him to London scholars. A day after Breyne arrived in Finis Lane in the English capital, on 11 August he visited the London apothecary at his home. He described his first personal contacts with Petiver in the following manner: 'NachMittag ging ich bey Hr. Petiver, welcher mich gantz höfflich empfing, mich sehen liesse eine grosse Quantität von seinen Insectis. Dernach lis er mich sehen eine Anatomiae eines Knabens Colica convulsium annecati [...]. Vor denen führte er mich auf ein Coffe House als wo die vornehmsten Membrae Societatis Regiae als [...] der Secretarii Hans Sloane, Doctor Hotton, und andere versammelt [...] welche mich sehr höflich empfangen [...]. In der Assamble wurden von allerhand Sachen discutiret, doch meisten Englisch [...]. Das Abends ging ich noch mit dem Hr. Petiver in einen Tavern, alwo er mich mit Essen und trinken regalirte'. One day later Breyne went to Hampstead with Petiver and Doody, and then met W. Sherard, who introduced him to another scholar with whom he visited Fulham and the Bishop of London's garden with plants from Virginia and New England acclimatised there. Over the following days Doctor Doody showed the visitor from Gdańsk the medical garden he managed at Chelsea and other sites. On 6 September Breyne visited Sloane at his private residence for the first time. For more, see 'J.P. Breyne. Reisetagebuch 1. Januar bis 31. Dezember 1702', FB Gotha, Chart. B 966, passim. Cf. also the correspondence from the period between Breyne, Petiver and Sloane preserved in the BL as well as entries from Breyne's album amicorum ('Stammbuch 1702 [bis 1722]', FB Gotha, Chart. B 1002, fol. 37, 38, 40-42, 46-73, 79, 86).

${ }^{59}$ Petiver's most important letter to Johann Philipp Breyne from the 1700s, which features a direct reference to Breyne's scholarly activity, is BL, Sloane Ms 3335, fol. 51a-52b. Part three of the present article [forthcoming] focuses on Johann Philipp Breyne's correspondence with the Englishmen after his departure from Polish Prussia on his peregrinatio medica. 
material documenting the Breynes' contacts with the English, ${ }^{60}$ contacts which would develop in the eighteenth century thanks to Johann Philipp Breyne and his friendship with Petiver, Sloane and William Sherard. ${ }^{61}$ The letters reveal how books, naturalia and various artefacts circulated between Western and Central-Eastern Europe. They also reveal the principles of reciprocity and friendship followed by scholars studying the res herbaria and historia rerum naturalium.

The published letters and their drafts can be found in the British Library in four units from the Sloane manuscripts collection. The present edition has been prepared in accordance with the rules of the Sloane Letters/Reconstructing Sloane projects. ${ }^{62}$ The heading of each source features a number, data on the sender and addressee of the letter, the date (whenever possible) as well as information about the basis of the edition with archive-library call number. The text has not been modernized, nor has the original alineation been maintained. Grammatical and punctuation errors have been left unchanged, as they do not distort the text or make it incomprehensible. Uncertain variants are marked with [?]. Basic textual notes have been added.

(Translated by Anna Kijak)

\section{SOURCE TEXTS}

1.

\section{Draft of an anonymous translation into English of Jacob Breyne's Latin letter to James Petiver, undated Source: British Library, Sloane Ms 4066, fol. 271a-72a}

[fol. 271a] Honoured $S^{r}$

Your most welcome and to me most acceptable Ltr of the 22 of Febr: together with your present of the grasses dryed growing naturally \& spontaneously in your happy Britain, and I received the last Sum-

${ }^{60}$ Documents preserved in FB Gotha encompass letters exchanged between J.P. Breyne and Petiver in 1703-13, and between J.P. Breyne and Sloane in 1704-47.

${ }^{61}$ J.P. Breyne corresponded with sherard in 1702-27; letters from this period have been preserved in FB Gotha.

${ }^{62}$ See the websites of both projects: $\langle$ https://sloaneletters.com $\rangle$; $\langle$ https:// reconstructingsloane.org $\rangle$ [accessed 15 January 2020]. 
mer and indeed with no small joy: wherefore I am so much taken with it, that I cannot chuse, but render you my most hearty acknowledgmet as well for present received, as that if honour was chiefly procured by your Kindnisse means, insomuch as I make bold to reckon myself in the number of those, who honour \& admire you, altho, $S^{r}$ I must confesse that yourself, (together with the rest of those famous Botanists whose names by $\mathrm{M}^{\mathrm{r}}$ Ray $^{63}$ are with abundance of precise published to $\mathrm{y}^{\mathrm{e}}$ Learned world) was long ago by me highly valued and esteemed and to whosees deserts I confesse myself much oblig so that I should willingly have acquit ${ }^{\text {ed }}$ myself of the duty of a Letter which I ow as well to you as to $\mathrm{M}^{\mathrm{r}}$ Ray, $\mathrm{D}^{\mathrm{r}}$ Plukenet ${ }^{64} \& \mathrm{c}$ : and should have testified \& declared to them my gratitude, and readyness to do them any service, for that speciall favour, and singular honesty they have made appear at large, (in illustratening and advancing that noble science) to all true Lovers of it, and indeed to also succeeding Ages. But by reason of the daily inconveniencys from my unhealhy disposition, which do so much retard me as well in my the way of [essed employment as in all other buisnesses, so that ${ }^{\text {if }}$ I but have but the good fortune being but one week pretty well; I can ill bear the losse of it, I say I find so much businesse upon my hand, that if I were as strong as Hercules I could not be in a capacity to perform it. for I am evermore thwarted \& hindered in my purpose, insomuch that I perceive an absolute [illegible word] these hindrances of begging your pardon for my so long delaying to answer your kind Lre, and with all most humbly to beseech you (worthy $\mathrm{S}^{\mathrm{r}}$ ), that [illegible word] would complete this your kindniss to me, and when it shall be convenient and fasonable that you would please to present my most humble respects \& service to $\mathrm{M}^{\mathrm{r}}$ Ray and the other renouned lovers of $\mathrm{y}^{\mathrm{e}}$ Botanic art, stand how much I esteeme, \& and admire such eminent and worthyly excellent \&c persons. To whom also I superaddi this wish, that it would please almighty God of his great mercy to preserve in Health \& prosperity both yourself (worthy $S^{r}$ ) as also those other noble gentlemen ${ }^{\text {still }}$ many years longer to $\mathrm{y}^{\mathrm{e}}$ glory of His great name, and to the finishing and adorning of their noble workes, and they may prosper and flow risk in all the blessing of body \& mind, to the great benefit \& advance. of posterity.

${ }^{63}$ John Ray (1627-1705) - English cleric and naturalist associated with the Cambridge University, proponent of physicotheology, author of new systems of plant classification.

${ }^{64}$ Leonard Plukenet (1641-1706) - English botanist, royal gardener, collaborator of J. Ray. 
Besides I thought good to give you notice of some things, on the $22 \mathrm{Oc}-$ tob by $y^{\mathrm{e}}$ master of a vessell whose name is Joh: Witzches of Danzig, which ship is called the Castle of Danzig, viz, that there is a packet design to your worship with some Prussian plants \&c, which I took [illegible words] to get dried this sumer; with this Character upon it is also a box marked JB. with this living plants following. viz. calciolus mariae ${ }^{65}$ [illegible words] [fol. 271b] wish they may come safe \& well conditioned to your hands.

I should have also most freely have sent you more both of the dry \& live plants but being having laboured all last summer under a taedious indisposition, and not meeting with any one in this Citty, who could assist me in collecting \& drying the plants; this work lying wholly upon myself; this was all I was able to perform you meet with very few of the Submarin or Saxatil. plants because the places hereabouts are destitute of rocks and craggs. Neither do I find more of the Saxatils mentioned by Mr Ray in his Synopsis, ${ }^{66}$ then filix mariae aculeata major C.B prod ${ }^{67}$ and filix fontis somewhat resembling the $\operatorname{com}[\mathrm{m}]$ on male fern, ${ }^{68}$ or filix non dentate J.B and filix tenuissima profunde dentamaeilata Montbelgards. ${ }^{69}$

If God spare with life \& health, I shall dry them and most willingly praeserve them for your use. So likewise if I have but never so little more leisure I shall looke over my Exoticks and shall freely com[m]unicate some of them that I can well spare to yourself Sr. I should therefore be glad to understand if you want any Japan plants; $\mathrm{S}^{\mathrm{r}}$. I render you my most humble tankes for your favourable \& generous promise of making me happy with the remainder of the plants growing in England described by $\mathrm{M}^{\mathrm{r}}$ Ray. They will yield to me, when they are arrived aboundance of delight, both for the memory of your name by me highly esteemed and also to maintain to my Herball a friendly correspondence \& commerce of Lres. For truly if so be, it appear that there is any amongst the vast Number of plants from the 4 partes of the Earth, nay, or but any from Terra Australi incognita, I shall insert them. But especially I do mightily desire some of your submarin Saxatills \& grasses of the last of which [crossed out illegible

${ }^{65}$ Calceolus Maria - lady slipper orchid.

${ }^{66}$ John Ray, Synopsis methodica stirpium Britannicarum: in qua tum notae generum characteristicae traduntur, tum species singulae breviter describuntur: ducentae quinquaginta plus minus novae species partim suis locis inseruntur, partim in appendice seorsim exhibentur: cum indice \& virium epitome, London, 1690.

${ }^{67}$ The plant was described in Bauhin's Pinnax (Caspar Bauhin, Pinax Theatri Botanici...: sive index in Theophrasti, Dioscoridis, Plinii et Botanicorium qui a saeculo scripserunt opera, Basel, 1623) and not Prodromus (idem, Prodromus Theatri Botanici, Frankfurt am Main, 1620).

${ }^{68}$ Male fern - dryopteris filix-mas.

${ }^{69}$ Johann Bauhin, Historia novi et admirabilis fontis balneique Bollensis, Montbéliard, 1598. 
words] I suppose if not so many, yet at least not much fewer may heve be found then are contained in the Synopsis of the famous $\mathrm{M}^{\mathrm{r}}$ Ray. I obtaind at last not without a great deal of difficulty from $\mathrm{D}^{\mathrm{r}}$ Pluckenet himself about 3 or 4 months ago His Phytographia ${ }^{70}$ and I assure you I turned it over \& over with extraordinary satisfaction, I have a great mind to those plants, that is to say if it be possible to procure them Absynthium minus odorat[us] \&c.

I am now fully resolved to publish my Viridariu[m] of Prussia \& Cassubia, as soon as ever I shall get leave of ${ }^{\text {my }}$ weakness, to take a journey one summer more through Prussia \& Cassubia to take a view and reckon up those plants which I had determined to have seen this year, and had made some beginning too with with wonderfull success as to the observations, tho' my health was not answerable to ye successes for it suffer much impairement thereby.

As for my Fasciculus $y^{\mathrm{e}}$ best part of it is complete, and ready for the presse; but I pause a while before I publish it, till I see whether Herman will put out his Paradisus Batavica, ${ }^{71}$ for I have notice $\mathrm{y}^{\mathrm{t}}$ he hath quite finished the work, and that he waites till my work comeout (which don, he will commit his own to $y^{\mathrm{e}}$ presse. But truly then I expect no other fate to attend this my work then that $\mathrm{w}^{\mathrm{ch}}$ my Prodromus Secundus ${ }^{72}$ met withall, which by me being published in $\mathrm{y}^{\mathrm{e}}$ year 89 in the moneth of April, Hermann afterwards in the Mon: of August obtrudes to the world his Prodromus Paradisi ${ }^{73}$ \&c.

In which work Herman makes much use of my names, without so much as ever mentioning my name, which indeed is very disingenuous \& never put in practice neither in the times of Scaliger, ${ }^{74}$ Clusius, ${ }^{75}$ Columna, ${ }^{76}$ the

${ }^{70}$ Leonard Plukenet, Phytographia Sive Stirpium Illustriorum \& minus cognitarum Icones tabulis aeneis. Summâ diligentiâ elaboratae; Quarum unaquaeq[ue] Titulis descriptoriis ex notis suis propiis, \& characteristicis desumptis, insignita, ab aliis ejusdem Sortis facile discriminatur. Pars prior, London, 1691. Part two was published in the same year, part three in 1692, and the fourth part - in 1696.

${ }^{71}$ Paul Hermann, Paradisus Batavus, continens Plus centum Plantas affabrè aere incisas $\&$ Descriptionibus illustratas. Cui accessit Catalogus Plantarum, quas pro Tomis nondum editis, delineandas curaverat Paulus Hermannus, M.D. In Academia Lugduno-Batava nuper Medicinae ac Botanices professor. Opus Posthumum, Leiden, 1698.

72 Jacob Breyne, Prodromus fasciculi rariorum plantarum secundus, exhibens catalogum plantarum rariorum, anno M.DC.LXXXIIX. in hortis celeberrimis Hollandiae observatarum..., Gdańsk, 1689.

${ }^{73}$ Schola Botanica Sive Catalogus Plantarum, quas ab aliquot annis in Horto Regio Parisiensi Studiosis indigitavit Vir Clarissimus Joseph Pitton Tournefort, M.D.: Ut Et Pauli Hermanni P.P. Paradisi Batavi Prodromus, Amsterdam, 1689.

${ }^{74}$ Julius Caesar Scaliger (1484-1558) - Italian humanist interested in natural history.

${ }^{75}$ Charles de L'Écluse (1526-1609) - Flemish doctor and botanist.

${ }^{76}$ Fabio Colonna (1567-1640) - Italian naturalist interested primarily in botany. 
2 Bauhins ${ }^{77}$ nor the other [fol. 272a] famous Botanists of that age. ${ }^{\&}$ which was all together avoided by the prudent, upright Mr Ray in this our daies. I writt these lines in very great hast, ye out of kindnisse to you, withe [illegible d]... of my health, Sr I command you to the keeping of $\mathrm{y}^{\mathrm{e}}$ Almighty and shall remain to the utmost of my power

$\mathrm{Sr}$

Your most humble admirer and reall friend Jacob: Breynius

P.S. The Cassubian \& Prussian plants not described I earnestly begg that you will not suffer them to be published, because I do design and figure them myself for the publique.

If I shall change to somewhat slow in answering your Lre pray dont thereby call in question my respect and gratitude towards you, for although my duty and respect to you be long in appearing, yet I shall do my endeavour $S^{r}$, to give you some essentiall proofes of them some other way. If my small garden plot can be next sum[m]er be enlarged and made happy but with some branch or others of $y^{\mathrm{e}}$ Tulip bearing tree 1.2.3. and of Liquid amber and of others that $y^{r}$ Indy's produce, I shall acknowledge myself $S^{r}$ to be extreamely obliged by $y^{e}$ favour $S^{r}$ if you shall please to transmit to me any of the dryed plants the next spring, you may send them to Wilhelm Hen: Cornellison and may be further directed to my sonn Jacob: Breynius junior in Dantzick.

NB. That you should be at a los for [?] aboard what ship I have put the bundle with the box directed to you, I have written to $\mathrm{y}^{\mathrm{e}}$ Skipper Wilh: Hen: Cornellisen some time ago to certify you of $y^{e}$ same.

2.

Draft of James Petiver's letter to Jacob Breyne, undated, most likely 24 December 1695 Source: BL, Sloane Ms 4067, fol. 81a-81b

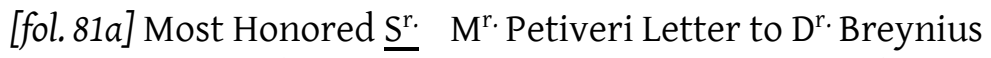

$\mathrm{Y}^{\mathrm{r}}$ very Oblidging \& most Welcome Letter, Dated from Dantzick $\mathrm{y}^{\mathrm{e}}$ $5^{\text {th }}$ of November 1692. I Received $y^{\mathrm{e}} 18^{\text {th }}$ of $y^{\mathrm{e}}$ same month Old Stile with aboundance of Joy \& Satisfaction, as also $y^{\mathrm{e}}$ day before Yesterday (after

${ }^{77}$ Johann (Jean) Bauhin (1541-1613) - Swiss botanist from Basel, physician to Frederick I, Duke of Württemberg. In pre-Linnaean botanical works plant species described by him were referred to by the initials J.B. Gaspard (Caspar) Bauhin (C.B.) (1560-1624) - Swiss botanist, professor of Greek, anatomy and botany at the University of Basel. 
a great many Cares \& Fears) that most incomparable Collection of $\mathrm{y}^{\mathrm{e}}$ most Curiousest preserved Plants that ever I saw, with $\mathrm{y}^{\mathrm{r}}$ Box of Books came safe \& well to my Hands, through $\mathrm{y}^{\mathrm{e}}$ Extraordinary Care of that Worthy \& Oblidging Genteman $\mathrm{M}^{\mathrm{r}}$. Will. Hen. Cornelisson $\mathrm{y}^{\mathrm{e}}$ Merch[ant], to whom I am extreamly Oblidged not only for his Civility but his great Diligence in Speedily conveying $\mathrm{y}^{\mathrm{m}}$ to me.

And to you Most Honored $\mathrm{S}^{\mathrm{r}} \mathrm{y}^{\mathrm{e}}$ most Consumable \& Judicious Botanist I send my most hearty thankes, hoping you will Excuse my Insufficiency, because I want words to Express how much $\mathrm{y}^{\mathrm{r}}$ most Noble Present, deserves my true Anknowledgments. But Be pleased to rest assured I will for $y^{\mathrm{e}}$ Future strive to Deserve $\mathrm{y}^{\mathrm{r}}$ Accumulated Favours, \& I will God willing by the first Shipp \& as often as Opportunity serves make you some Retalliation. I being not a Little Proud of having $\mathrm{y}^{\mathrm{e}}$ Honour of Coresponding with so Generous \& Noble a Patron.

YesterNight att a Weekly Meeting of Botanick Friends, amongst whom were Present $\mathrm{y}^{\mathrm{e}}$ Ingenious $\mathrm{D}^{\mathrm{r}}$ Plukenett, $\mathrm{D}^{\mathrm{r}}$ Sloan, $\mathrm{D}^{\mathrm{r}}$ Robinson, ${ }^{78}$ $\mathrm{M}^{\mathrm{r}}$ Newton, ${ }^{79} \mathrm{M}^{\mathrm{r}}$ Doody, ${ }^{80} \mathrm{M}^{\mathrm{r}}$ Dale, ${ }^{81} \mathrm{M}^{\mathrm{r}}$ Du-Bois ${ }^{82} \& \mathrm{c}$, who all dranke \& wisht $\mathrm{y}^{\mathrm{u}}$ health \& earnestly desired their Respects \& Service might be sent to you, with their Thankes as well for $\mathrm{y}^{\mathrm{e}}$ kind Remembrance you was Pleased to Express of them as for those Noble \& great additions \& Discoveries you have been Pleased to communicate to $\mathrm{y}^{\mathrm{e}}$ World in $\mathrm{y}^{\mathrm{e}}$ Recreative Science of Botany.

$\mathrm{D}^{\mathrm{r}}$ Plukenet $\mathrm{y}^{\mathrm{e}}$ honorous Botanist hath a very lately Published a $2^{\mathrm{d}}$ Vollum of his Phytographia $\mathrm{w}^{\mathrm{ch}}$ rather exceeds $\mathrm{y}^{\mathrm{e}}$ Equally his other book both in elegancy \& variety it consists of 130 Tables Dedication to $\mathrm{K}$. William ${ }^{83}$ of whose Gardens he is made supervisor. What specimens I have both of his first \& $2^{\mathrm{d}}$ Vollum I will send by $\mathrm{y}^{\mathrm{e}} 1^{\text {st }}$ Shipp. [overwritten word, illegible].

78 Tancred Robinson (1658-1748) - English doctor and naturalist, physician to George I.

${ }^{79}$ Isaac Newton (1643-1727) - English natural philosopher interested in botany since his studies at Cambridge. For more on this, see David J. Beerling, 'Newton and the Ascent of Water in Plants', Nature Plants, 1, 2015, 2, article number 15005, $\langle$ https://doi.org/10.1038/nplants.2015.5〉.

${ }^{80}$ Samuel Doody (1656-1706) - English apothecary and botanist, from 1693 until his death director of the Apothecaries' Garden at Chelsea.

${ }^{81}$ Samuel Dale (1659-1739) - English physician and naturalist, author of works devoted to the materia medica.

${ }^{82}$ Charles Du Bois (1656-1740) - merchant and treasurer of the East India Company, owner of a garden at Mitcham.

${ }^{83}$ William III of Orange (1650-1702) - from 1672 Stadtholder of the United Provinces, from 1689 King of England, Scotland and Ireland. 
From $\mathrm{D}^{\mathrm{r}}$ Sloane $\mathrm{w}^{\mathrm{d}}$ an Promised a Nat. History of $\mathrm{y}^{\mathrm{e}}$ Iland Jamaica in $\mathrm{y}^{\mathrm{e}} \mathrm{W}$. Indies in folio illustrated with Icons ${ }^{84}$. He is a most Inquisitive \& Learned Physitian and a Person extreamly well qualified for suit a Design He went to $y^{\mathrm{e}}$ Iland Physitian to $\mathrm{y}^{\mathrm{e}} \mathrm{D}$. of Albermale ${ }^{85}$ then Governour then of, after whose Death he returned plentifully Stockt with a Copious variety of all Naturall Productions especially Plants. He is my Particular \& Honored Friend, \& one to whom I am much Obliged He hath shewed me amongst an Infinite Numbre of other rare Plants neer 100 Ferns most of $\mathrm{y}^{\mathrm{m}}$ undiscribed $\mathrm{w}^{\mathrm{ch}}$ he himself gathered in $\mathrm{y}^{\mathrm{e}}$ Island.

[fol. 81b] My unseigned \& intimate cordial Friend \& Brother $\mathrm{M}^{\mathrm{r}} \mathrm{Sam}^{\mathrm{tt}}$ Doody is lately elected Master of $\mathrm{y}^{\mathrm{e}}$ Worthy Company of Apothecarys Physicks Garden in the Room of $\mathrm{M}^{\mathrm{r}} \mathrm{John}$ Watts ${ }^{86}$ who though He left it very bare \& allmost totally deprived of Curious Plants never $\mathrm{y}^{\mathrm{e}}$ less it will in a very few years through $\mathrm{y}^{\mathrm{e}}$ great care $\&$ indefatigable Industry of its present Supervisor, be Replenished with such variety of as well Forreign as Domestic ${ }^{\text {Plants }}$ neh will not only afford extream Delight to all $y^{\mathrm{e}}$ Ingenious Lovers of this most pleasant Invocant \& Divertive Sciences of Botany. But also gain immortal Honour both to himself \& to $\mathrm{y}^{\mathrm{e}}$ Worth Company of Apothecarys, these Honorous Patrons \& Incourageus of so Useful \& Necessary a Branch of Physick, $\mathrm{y}^{\mathrm{e}}$ abovementioned $\mathrm{M}^{\mathrm{r}}$ Doody designs this Spring to publish his Historia Plantarum Submarinam Fungoru $[\mathrm{m}]$ Muscoru[m]\& multis figuris illustratae, ${ }^{87}$ Of each of these prints I will send you some by $\mathrm{y}^{\mathrm{e}}$ first Shipping as also $\mathrm{w}^{\mathrm{t}}$ Ferns I have by me, \& will be more ample as soon as he shall have Published his History, $\mathrm{w}^{\text {ch }}$ had been done ever this had not $\mathrm{y}^{\mathrm{e}}$ Preservation of $\mathrm{y}^{\mathrm{e}}$ Physick Garden been his greater Diversion, \& Most Worthy $\mathrm{S}^{\mathrm{r}}$ I shall endeavour to send you, $\mathrm{w}^{\mathrm{t}}$ Rarities our Gardens afford, assoon $\&$ as often as Conveniency will give permission.

Most honored $\mathrm{S}^{\mathrm{r}}$ I return you my hearty thanks for $\mathrm{y}^{\mathrm{e}}$ generous proffes \&c you was pleased to make me in sending Samples of $y^{\mathrm{r}}$ Indian and Japan Plants some \& I let me assure you, $\mathrm{y}^{\mathrm{e}}$ arrivall of $\mathrm{y}^{\mathrm{e}}$ meanest you can spare from $\mathrm{y}^{\mathrm{r}}$ Collections will be most infinitely Acceptable to me, \& with equall esteem I should I should be proud to receive $\mathrm{w}^{\mathrm{t}}$ Ferns you can spare.

${ }^{84}$ The work in question is Sloane's two-volume A voyage to the islands Madera, Barbados, Nieves, S. Christophers and Jamaica..., cf. note 34.

${ }^{85}$ In 1687 Sloane went to Jamaica with Christopher Monck to become his physician. For more on the subject, see Delbourgo, Collecting the World, passim.

${ }^{86}$ John Watts - English apothecary, merchant and director of the Apothecaries' Garden at Chelsea in 1680-92/3. J.G.L. Burnby, 'The Career of John Watts, Apothecary', Pharmaceutical Historian, 21, 1991, 1, pp. 4-5.

${ }^{87}$ Samuel Doody never published such a work, but he did help Ray with his books. 
Worthly $\mathrm{S}^{\mathrm{r}}$ I had answered $\mathrm{y}^{\mathrm{r}}$ Letter before this, but though it would be more Convenient to stay till I could together with it give you an Account of the receiving $\mathrm{y}^{\mathrm{r}}$ Most Noble present, $\mathrm{w}^{\mathrm{ch}}$ most honored $\mathrm{S}^{\mathrm{r}}$ I thanke God \& you after many anxious doubts \& fears came safe to my hands. $\mathrm{M}^{\mathrm{r}}$ Cornelisson tells me $\mathrm{y}^{\mathrm{t}} \mathrm{y}^{\mathrm{e}}$ same Shipp will depart from London $a^{\text {bt }}$ a Month hence \& by her you may Expect to receive something of $\mathrm{w}^{\text {ch }}$ I will with them give you a further Account.

If in $\mathrm{y}^{\mathrm{e}}$ Interim Dear $\mathrm{S}^{\mathrm{r}}$ you will be so pleased to let me know wherin I can particularly serve you, Pray write to me by $y^{\text {e }}$ first Post \& I will Obey you to $y^{\mathrm{e}}$ utmost of my Power.

Thus Dear Sir I conclude with my hearty Prayers to the Almighty for $\mathrm{y}^{\mathrm{e}}$ preservation of $\mathrm{y}^{\mathrm{r}}$ health, wishing you Long Life, all Happieness \& Prosperity. I am most Hon $S^{r} Y^{r}$ most Oblidged friend \& humble Servant

till Death James Petiver

London / Christmass Eve

\section{3.}

Jacob Breyne's letter to James Petiver

written by Jacob's fourteen-year-old son Johann Philipp,

18 May 1694

Source: BL, Sloane Ms 3321, fol. 9a-13a

[fol. 9a] Excellentissimus \& Noblissimus Dominus.

Excellentiam vestram hisce meis compellare literis audeo, jussu domini Parentis mei, et quidem ex quo tempore ad excell. Vram. literas misit valetudinarii et inter caeteros affectu quodam in manib[us] infestati, qui interdum mitigatus, interdum tamen accrevit, ut toto illo temporis spatio literaru[m] officio vix fungi, imo ad curiosos tam intra quam extra Europam negligere fuerit coactus. Hac causa mot[us] magnopere petit et contendit, ne intermissum officii iniquo ferre velit Excell. Vra. amore, ad literas quas ab Excellent. Vra superiore ut et hoc anno (quamquam ultima ante aliquot dies) accepit. Est igit[ur] quo Honaratissimus $\mathrm{D}^{\mathrm{n}[\mathrm{us}]}$ Parens pro plantis ressiccatis missis sibi muneri maximas agat gratias, laudabile[um] studium et accuratissimam Excell. Vrae in minutissimis quoq[ue] museis observationem, quae maxime ei est voluptati; gratuletur, eam quoq[ue] ut praeter Dei gloria[m] immortali laudi et Posteris utilitati cedat animo praecet[ur]. Quod autem ad plantas vivas quarum in literis [fol.10a] mentionem fecit attinet, $D^{\text {um. }}$ Par. non accepisse sciat Excellent. Vrae. Pro caeterisresiccatis plantis exoticis q[ue] seminib[us] quae Excell. Vra. Dno. Parenti muneri se missuram promisit; gratias agit: imflamabil[us] $\mathrm{D}^{\text {um }}$ Parenti ad officium suum jam diu debitum omni tempore declarandum et 
cumulatissime reddendum. Quocunq[ue] igit[ur] tempore Excell. Vrae jam dictas plantos mittere placuerit; reliqua in Anglia sponte nascentia Gramina praesertim a Dno Raio solo descripta, addi obnixe rogat (quia $\mathrm{D}$ [omi]n[us] Parens anno superiore illa tantum in catalogo addito nominata accepit: an omnia, ignorant) ne viridarium Prutenicum sine necessitate novis nominib[us] impleat, sed eo magis cum $\mathrm{D}^{\text {o. }}$ Raio (cujus descriptiones interdum brevissimae et obscurae) faciat. Sub finem auctumni superioris $\mathrm{D}$ [omi]n[us] parens Exc Vrae capsulam signata[m] $R$ per nautam Joachim Wilskes transmisit, cum sequentib[us] plantis vivis: ut cum $n^{\circ}$. 1. Pulsatill. A pii folio, laciniis latiorib[us]. $\mathrm{N}^{\circ}$. 2. eadem laciniis angustioris [fol.11a] $\mathrm{N}^{\circ}$. 3. Pussatilla flor. clause obsoleto, $\mathrm{N}^{\circ} .4$. Lunaria multifido folio, ${ }^{88} \mathrm{~N}^{\circ} \cdot 5$. [illegible word] Prutenica flo-radice dulci lobis foliorum mutantib[us] Breyn. $\mathrm{N}^{\circ}$. 6. Saxifraga autumnalis angustifolia fl[ore] luteo punctato. Breyn, ${ }^{89} \mathrm{~N}^{\circ} .7$. Gentian[a] fl[ore] guttato. $\mathrm{N}^{\circ}$. 8. Pyrola Arbutifolio. $\mathrm{N}^{\circ}$. 9. Pyrola fl. luteo virescentae Breyn. $\mathrm{N}^{\circ}$. 10. Pyrola oblongofolia serrata. $\mathrm{N}^{\circ} .11$. Orchide radice repente, dimidiam partem earum Excelle. Vrae alteram vero $\mathrm{D}^{\text {no. }}$ Doody, navis frigore et glacie impedita; [Domi]n[us] Parens dubitat an incolumnis mare trajecerit, quod damnu[m] recuperate valetudine si dues voluerit future autumno Se resarcire velle pollicet[ur], Gravissimus quo $\mathrm{D}^{\mathrm{n}[\mathrm{us}]}$ Parens jam diu conflictatus est morbus, cum lecto perpetuo fere affixum, nec ultra septies in publicum egressum domi Se tenere coegit, iter quoq[ue] quod in desertum Waldon et in totam Borussiam praesentim in illam partem, quae Poloniae, Lithuaniae et Samogitiae adjacent superior [three unintelligible words, leaf cut] induxerat conficere [fol.12a] prohibitum impedivit, Ne viridariu[m] in vulgus edere posset; ante illud enim iter id edere ei non animo fuit. Fasciculus rariorum plantarum quoq[ue] nondum in lucem editus est, cui tamen absolvendo, publicisque jurisq[ue] faciend \& operam navabit. Hoc facto D. ${ }^{\text {[us] }}$ Parens promissis quae fecit Excell. Vrae Japonicarum Plantarum causa salis faciet. Plantas in terra Australis incognita nascentes libentissime transmitterat, sed paucissimae sunt et quide singulae. De Prutenicis quas Excell Vra desiderat statim post editionem viridarii mittet, hoc tantum rogat, ne nondum descriptae Prutenicae Plantae, quas D. ${ }^{\text {[us] }}$ Parens Excell. Vrae misit, publicentur, priusquam viridariu[m] in lucem ediderit.

Partem 3. ${ }^{\text {am }} D^{\text {ni }}$ Plukenetii D. ${ }^{\text {n[us] }}$ Parens accepit, nec $D^{\text {n[us] }}$ Cornelisson pecuniam solvisse et ipsi[us] nomine [fol.13a] debitas egisse gratias dubitat. Herbae quae ex Codice Haemptoniensi in illa depictae omnes anno

${ }^{88}$ Plant described by J. Breyne in his Centuria, p. 184, fig. 95.

${ }^{89}$ Plant described by J. Breyne in his Centuria, p. 106, fig. 48. 
1685. a $D^{\text {no }}$ Van der Ste ${ }^{90}$ Gubernatore Promentorii Bona Spei in itinere suo maximo q[uod] fere as 100 milliaria Germanica in illa[m] terra[m] fecit observatae \& depictae in Hollandiam transmissae sunt: omnes quoq[ue] haru $[\mathrm{m}]$ icones acuratas\& satis magnas $\mathrm{cu}[\mathrm{m}]$ quibusdam illarum[m] resiccatis plantis $\mathrm{D}^{\mathrm{n}[\mathrm{us}]}$ Parens accepit. Et ingenue confitetur quasdam earu[m] a $\mathrm{D}^{\text {no }}$ Pluckenetio in lucem edituram optime \& accuratissime, nonnullas vero male\& minus naturae convenientes depictas esse: sicut Excell. Vestra ex illis de quibus in Fasciculo mentio fuit distincta \& clare judicare poterit. $D^{\text {[omi]n[us] }}$ Parens ex Hollandia Semina quaedam Indica \& Africana accepit sed quia Excell. Vestr[ae] sine dubio eadem quoq[ue] obtinuerit, dubitat an Excell. Vestrae grata futura sint.

$\mathrm{D}^{\text {[omi]n[us] }}$ Parens adhuc humanissime Excell. $\mathrm{V}$ [est]ra[m] (quam summa veneratione diligit \& aestimat) rogat, ne aegre ferre, sed etiam apud $\mathrm{D}^{\text {[omi]n[um] }}$ Doody excusare velit $q d$ ipse literas alterius non vero sua manu scriptas miserit Morbus enim omnino prohibet, sine non mediocri affectus tristia, quoniam se multum neglexisse videt; imo nescit quem laborem prae ceteris valetudine recuperata sit suscepturus; tandem ut aliquando modum statuam literis, quas materiarumvarietasaequolongiores fecit Excell. Vestra[m]. Deo Triuno commendat $\mathrm{D}^{\mathrm{n}[\mathrm{us}]}$ Parens ejus benedictionem in omnibus laboribus precatus, quo in rei litterariae usum vergere possit eadem gratiam Divinis Numinis suavissima salutatione promissa \& ego precor

Excellentiae Vestrae Gedan.: Maii 18. 1694 ad omnia officia paratissimus Cliens Johannes Philippus Breynius. Jacobi Filus.

P.S. Ad resiccatas plantas qa attinet qvas Excell. Vra. muneri missurum se $\mathrm{D}^{\text {no }}$ Parenti promissit, rogat, ut ita Navarcho commendentur ista in illud conclave ubi velaiacent custodiantur. In dormitoria Navis corrumpuntur ut Excell. Vrae. resiccatae plantae superiore anno transmissae situ obductoe erant.

\section{4. \\ Draft of James Petiver's undated letter to Jacob and Johann Philipp Breyne Source: BL, Sloane Ms 3321, fol. 14a}

[fol. 14a] Mr Breynius Jun ${ }^{\mathrm{r}}$

$\mathrm{S}^{\mathrm{r}}$ Having received no answer to my last Letter \& Collection $\mathrm{w}^{\text {ch }} \mathrm{I}$ delivered to $\mathrm{M}^{\mathrm{r}}$. Cornelisson $\mathrm{ab}^{\mathrm{t}}$ this time Whole Month, makes me

90 Simon van der Stel (1639-1712) - in 1679-91 commander and then in 1691-99 Governor of the Cape of Good Hope, a colony of the Dutch East India Company (VOC). 
they either miscarried or your Fathers indisposition makes him still more incapable of Writing; $w^{\text {ch }}$ last I very much fear, \& would $y^{\text {ef }}$ fore desire you would by $\mathrm{y}^{\mathrm{e}}$ next post after tho' let me or $\mathrm{M}^{\mathrm{r}}$ Cornelisson hear from you, after $\mathrm{w}^{\mathrm{ch}} \mathrm{I} \mathrm{wu}^{\mathrm{d}}$ send another Collecti[o]n of dry Specimens with some other things $\mathrm{w}^{\text {ch }} \mathrm{I}$ hope will be acceptable to him as also a New adition of Mr Rays Synopsis stirpi[um] Britanicorum ${ }^{91}$ in $\mathrm{w}^{\text {ch }}$ are several undescribed Plants not mentioned by any before, I will also send aittle book I have lately printed of such Plants Shells \& Insects as I have observed in England or have been sent me from abroad with a Collection of the things I therein mention. I would humbly desire $y^{r}$ Father \& you would oblige some Person this spring \& sum[m]er to make a Collection of $\mathrm{w}^{\mathrm{t}}$ ever Insects are to be found about Prussia \&c. viz: Papiliones, Phalans, Muscae, Libellae, Apes, Scarabei, Locustae \&c. as also $y^{e}$ different sorts of shells as well there on land as sea \& fresh water.

If $y^{\mathrm{r}}$ Father will be pleased to send me something of each of these though never so few by the first shipp roath \& dry samples of what plants He Has by him $\mathrm{y}^{\mathrm{t}} \mathrm{He}$ can spare I shall think myself highly obliged to him \& will endavour to make a rettaliation to $\mathrm{w}^{\mathrm{t}} \mathrm{ever} \mathrm{Fa}-$ veure he shall confer upon.

Most Worthy $S^{r}$ Your and $Y^{r}$ Fathers most obliged \& humble Serv ${ }^{t}$ whilst J. Petiver

5.

Draft of James Petiver's letter to Jacob and Johann Philipp Breyne, 12 November 1697

Source: BL, Sloane Ms 3333, fol. 178b-79a

[fol. 178b] Most Worthy $\mathrm{S}^{\mathrm{r}}$ Monsieur Breynius

The Honour $\mathrm{y}^{\mathrm{r}}$ late (yet still most renowned \& celebrated) Father did me in favouring me with a Correspondence \& enriching me with this most curious Collections [overwritten words, illegible] w ${ }^{t}$ My great that I have neither words sufficiently to express $\mathrm{y}^{\mathrm{m}}$ nor ability to retaliate $\mathrm{y}^{\mathrm{m}}$ So $\mathrm{Y}$ my loss in so great \& generous a Benefactor \& Patron is inconsolable $\& \mathrm{w}^{\mathrm{t}} \mathrm{I}$ can never expect to retrieve without $\mathrm{y}^{\mathrm{e}}$ same innate goodness in you $\mathrm{w}^{\text {ch }}$ lived in $\mathrm{y}^{\mathrm{r} \text { noble }}$ Father ${ }^{\text {sent }}$ will be pleased to continue ye same to me in a frequent Correspondence \& mutuall correstion of such Curiosities in Nature as each other can spare. His

${ }^{91}$ Ray, Synopsis methodica stirpium Britannicarum. 
And that I may not be wanting in retaliation of what I have already or shall [overwritten words, illegible] receive from you whatever Plants are in $\mathrm{M}^{\mathrm{r}}$ Rays Catalogue or Synopsis of English Plants that you want samples of be pleased to send me a Catalogue of them \& I will forthwith send them or whatever else y shall desire. If I had a List of $y^{r}$ Fathers Exotick \& Prussian plants I could be $\mathrm{y}^{\mathrm{e}}$ better able to judge what you wanted $\mathrm{y}^{\mathrm{m}}$ I might have to spare $\mathrm{w}^{\mathrm{ch}}$ I would most freely send you. I have lately had $\mathrm{y}^{\mathrm{e}}$ honour \& satisfaction of seeing $\mathrm{y}^{\mathrm{e}}$ worthy Gentelman $\mathrm{y}^{\mathrm{r}}$ Brother in whose Face I understand is the lively remains of $y^{r}$ immortal Father, his sudden departure prevented me from sending you any thing more at present then Dr Sloans Catalogus Plantarum Insula Jamaica ${ }^{92}$ I should be glad to hear how Botany \& other parts of Natural History flourishes in $\mathrm{y}^{\mathrm{r}}$ parts, \& $\mathrm{w}^{\mathrm{t}}$ Books on that subject either hath or will suddenly be printed on $y$-that about you. I this Sum[m]er w ${ }^{\mathrm{d}} \mathrm{y}^{\mathrm{r}}$ Fathers last most curieus Collection of East India plants [fol. 179a] $\mathrm{w}^{\mathrm{ch}}$ with that he sent me before of Prussia Plants \& higly value \& shall for ever preserve \& esteem them as lasting monuments of his generous Bounty. Besides $\mathrm{y}^{\mathrm{e}}$ Plants I am most particularly obliged both to him \& you for $\mathrm{y}^{\mathrm{e}}$ Insects sent me $\mathrm{w}^{\text {ch }}$ were very rare \& highly acceptable to me. Whatever ${ }^{\text {Plants }}$ Insects \& Shells Poland \&c affords I should be very glad to see I do design By $\mathrm{y}^{\mathrm{e}}$ next Opportunity to send you a Collection of each if assoon as this Comes to $\mathrm{y}^{\mathrm{r}}$ hands you will be pleased to honour me with a Letter \& therein let me know wherein I can be serviseable to $y^{u}$ hire in England you shall not with more Freedom com[m] and then be layed by

\section{Worthy $S^{r}$}

$\mathrm{Y}^{\mathrm{r}}$ Most Affectionate Friend and humble Sert. James Petiver London Nov[ember]: $12^{\text {th }} 1697$

P.S. When $\mathrm{y}^{\mathrm{u}}$ write Be pleased to direct For $\mathrm{M}^{\mathrm{r}}$ James Petiver Apothecary \& Fellow of $\mathrm{y}^{\mathrm{e}}$ Royal Society in Aldersgate Street London

A coppy of this was translated into German by $\mathrm{D}^{\mathrm{r}} \mathrm{Crieg}^{93}$

${ }^{92}$ Cf. note 32.

${ }^{93}$ David Krieg (1667-1713) - physician from Riga. In 1697-98 he lived with Petiver in his apothecary shop under the White Cross in Aldersgate Street, London. Thanks to the patronage of Petiver and Sloane he was also able to go on a journey to North America (Maryland) to collect naturalia there for a few months. During his stay in London he translated into English numerous French, Dutch, German and Italian texts for Petiver. For more see Stearns, 'James Petiver', pp. 247 (note 12), 255. 
6.

Draft of James Petiver's letter to Jacob and Johann Philipp Breyne, 24 June 1698

Source: BL, Sloane Ms 3333, fol. 179a-80b

[fol. 179a] Mons: Breyne A Mons: $:^{\mathrm{r}}$ Mons: Jean Philip Brayne a Dantzigue.

Houred ${ }^{\text {Worthy }} \mathrm{S}^{\mathrm{r}}$ \& my very much esteemed friend

$\mathrm{Y}^{\mathrm{r}}$ kind \& very acceptable Letter I this afternoon received \& in [illegible words] compliance to what you desire in immediately answering yours [overwritten words, illegible] \& return you in your own Language this rough \& indigested [crossed out words, illegible] Epistle [fol. 179b] Imprimis. I return $\mathrm{y}^{\mathrm{u}}$ my sincere \& hearty thanks for $\mathrm{y}^{\mathrm{e}}$ Honour $\mathrm{y}^{\mathrm{u}}$ don me (for I so I really esteem it) in promising me $\mathrm{y}^{\mathrm{r}}$ Friendshipp \& Correspondence $\mathrm{w}^{\mathrm{ch}}$ $\mathrm{y}^{\mathrm{r}}$ inco[n]soll. Father so far condescended as to Favour with But I blush to find \& for which I must really release you for stiling or rather flaterring me with $\mathrm{y}^{\mathrm{e}}$ title of Patron whose greatest ambition is to be your (as

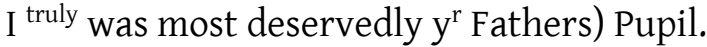

In relation to a Catalogue of $\mathrm{y}^{\mathrm{e}}$ dry samples or Specimens of $\mathrm{y}^{\mathrm{r}}$ Fathers Plants I only earnestly beg a List of such as he hath not already mentioned as also these that other Authors hath already described particularly Caspar Bauhine \& his Brother J.B. \& as to specimens I should be glad of whatever you can spare especially of such as $\mathrm{y}^{\mathrm{r}}$ Father hath already mentioned though $\mathrm{y}^{\mathrm{e}}$ Samples be never so small or [illegible word] be but me leaf of each specimen, be at of these if you please to annex but his name it will be highly acceptable \& prevent my publishing such for New as he hath already discovered, this I hope may without much trouble be effected, \& performed at over by looking over \& making a general review of all your Fathers plants.

[fol. 180a] I hope $\mathrm{y}^{\mathrm{e}}$ small time $\mathrm{y}^{\mathrm{r}}$ stay in Prussia $\mathrm{y}^{\mathrm{u}}$ will be pleased to make me a Collection of such Insects these parts afford especially of $\mathrm{y}^{\mathrm{e}}$ Papiliones \& Phalanae, as also $\mathrm{y}^{\mathrm{e}}$ Shells particularly I beg $\mathrm{y}^{\mathrm{u}}$ will send me such as are to be found in $\mathrm{y}^{\mathrm{e}}$ Fresh waters as Ditsches Ponds Rivuletts but above all these $\mathrm{y}^{\mathrm{t}}$ are found on dry land as in Gardens Woods Hedges $\& c$ this being a very opportune Season for them. You need only boyl out $\mathrm{y}^{\mathrm{e}}$ live Snail $\mathrm{y}^{\mathrm{e}}$ is in them \& so send $\mathrm{y}^{\mathrm{m}}$ to me.

I am very glad to hear $\mathrm{y}^{\mathrm{u}}$ design for Leyden \& hope when $\mathrm{y}^{\mathrm{u}}$ are so near England $\mathrm{y}^{\mathrm{u}}$ will be pleased to make a skip over, \& honour me with $\mathrm{y}^{\mathrm{e}}$ little of a [crossed out words, illegible] Member of our Royal Society $\mathrm{w}^{\text {ch }}$ I promise to procure you if you will favour us with your presence of wch in next pray give me some news I will endeavour to held a strickt \& frequent Correspondence with you whilst in Holland assoon as $\mathrm{y}^{\mathrm{u}}$ shall give me directions 
how I shall write to you but I do not expect these Botanick discourys from you then as $\mathrm{y}^{\mathrm{u}}$ are capable to make me out of $\mathrm{y}^{\mathrm{r}}$ ever living Father most incomparable Collection I am therefore inpatient to see what from them $\mathrm{y}^{\mathrm{u}}$ can spare me as also $\mathrm{y}^{\mathrm{r}}$ Extract out of Mr Ray Synopsis \& $\mathrm{w}^{\mathrm{t}}$ also $\mathrm{y}^{\mathrm{o}}$ want $\mathrm{y}^{\mathrm{t}}$ I can supply you with never shall more freely com[m] and them [fol. 180b] then $\mathrm{y}^{\mathrm{r}}$ selfe from him who is Most Kind \& Worthy $\mathrm{S}^{\mathrm{r}} \mathrm{y}^{\mathrm{r}}$ very much obleiged \& affectionate Friend \& humble Servant From \&c James Petiver

$\Upsilon^{94}$ Jun. 241698.

P.S. I very much long to hear from you wat I earnestly beg may be by $\mathrm{y}^{\mathrm{r}}$ first Occasion \& you shall not fail of being suddenly answered.

\section{Summary}

The British Library's Sloane Manuscripts Collection features the hitherto unknown late seventeenth-century correspondence between Jacob (1637-97) and Johann Philipp (1680-1764) Breyne, and James Petiver (1665-1718). The letters exchanged between Gdańsk and London in the 1690s document contacts between Jacob Breyne, one of the most important naturalists of the Polish-Lithuanian Commonwealth in the second half of the seventeenth century, and the London apothecary, along with other botanists and Royal Society fellows, including John Ray (1627-1705), Samuel Doody (1656-1706) and Leonard Plukenet (1642-1706). They also document the beginnings of contacts between the Gdańsk botanist's youngest son, Johann Philipp, and the London naturalist, who in the early eighteenth century introduced the young man to scholars from the English capital. The content of the letters reveals how books, naturalia (primarily exsiccata) and other artefacts (for example prints) circulated between Western and Central-Eastern Europe; it also demonstrates the principles of reciprocity and friendship followed by scholars studying natural history, and the functioning of the Res publica botanica (a unique manifestation of Res publica literaria). The article contains an edition of letters sent until 1698, that is, in the period preceding Johann Philipp Breyne's departure from Gdańsk to study medicine in the Netherlands, as well as an introduction discussing both Gdańsk scholars' early contacts with Petiver and other Royal Society fellows.

(Translated by Anna Kijak)

${ }^{94}$ Dies Mercurii - Wednesday. 


\section{Bibliography}

\section{Source editions}

The Correspondence of Henry Oldenburg, 13 vols, ed. and transl. A. Rupert Hall and Marie Boas Hall, Madison, WI: University of Wisconsin Press, 1965-86, vol. 2: 1663-1665, 1966, vol. 3: 1666-1667, 1966.

The Correspondence of John Ray: Consisting of Selections from the Philosophical Letters Published by Dr. Derham, and Original Letters of John Ray in the Collection of the British Museum, ed. Edwin Lankester, London: Ray Society, 1848.

\section{Secondary literature}

Barylewska-Szymańska, Ewa, and Wojciech Szymański, 'Gdańskie ogrody drugiej połowy XVIII w. w anonsach prasowych', in Gdańskie ogrody, Gdańsk: Muzeum Gdańska, 2018, pp. 57-119.

Beerling, David J., 'Newton and the Ascent of Water in Plants', Nature Plants, 1, 2015, 2, article number 15005, 〈https://doi.org/10.1038/nplants.2015.5〉.

Bujack, Johann Gottlieb, 'Über preußische Naturforscher des 16ten, 17ten und 18ten Jahrhunderts: Bibliografischßliterärische Skizzen: Die Danziger Jacob Breyn, Johann Philipp Breyn und Jacob Theodor Klein', Preußische Provinzial-Blätter, 23, 1840, pp. 193-209, 344-59.

Burnby. J.G.L, 'The Career of John Watts, Apothecary', Pharmaceutical Historian, 21, 1991, 1, pp. 4-5.

Clokie, Hermia Newman, An Account of the Herbaria of the Department of Botany in the University of Oxford, London: Oxford University Press, 1964.

Cooper, Alix, Inventing the Indigenous: Local Knowledge and Natural History in Early Modern Europe, Cambridge, MA: Cambridge University Press, 2008.

Coulton, Richard, " "What He Hath Gather'd Together Shall Not Be Lost”: Remembering James Petiver', Notes and Records: The Royal Society Journal of the History of Science, 74, 2020, 2, pp. 189-211.

de Jong, Marco, et al., 'The Book Herbaria of Jacob Breyne (1637-1697) in the Collection of Naturalis Biodiversity Center (Leiden, the Netherlands)', Taxon, 2021, ahead of print, 〈https://doi.org/10.21203/rs.3.rs-885416/v1〉.

Delbourgo, James, Collecting the World: The Life and Curiosity of Hans Sloane, London: Allen Lane, 2017.

Fleischer Alette, 'Breyne's Botany: (Re-)locating Nature and Knowledge in Danzig (circa 1660-1730)', in Locations of Knowledge in Dutch Contexts, ed. Fokko Jan Dijksterhuis, Andreas Weber and Huib J. Zuidervaart, Leiden: Brill, 2019, pp. 107-35.

Fleischer, Alette, 'Gardening Nature, Gardening Knowledge: The Parallel Activities of Stabilizing Knowledge and Gardens in the Early Modern Period', in Gar- 
dens, Knowledge and the Sciences in the Early Modern Period, ed. Hubertus Fischer, Volker R. Remmert and Joachim Wolschke-Bulmahn, Basel: De Gruyter, 2016, pp. 289-304.

Hunt, Arnold, 'Under Sloane's Shadow: The Archive of James Petiver', in Archival Afterlives Life, Death, and Knowledge-Making in Early Modern British Scientific and Medical Archives, ed. Vera Keller, Anna Marie Roos and Elizabeth Yale, Leiden: Brill, 2018, pp. 194-221.

Kurkowa, Alicja, Jakub i Jan Filip Breynowie: studium z dziejów kultury książki XVII i XVIII wieku, Wrocław: Zakład Narodowy in. Ossolińskich, 1989.

Notes and Records: The Royal Society Journal of the History of Science, 74, 2020, 2 (Special Issue: Remembering James Petiver).

Ogilvie, Brian W., The Science of Describing: Natural History in Renaissance Europe, Chicago, IL: University of Chicago Press, 2006.

Pękacka-Falkowska, Katarzyna, 'Flora rodzima w badaniach Jacoba Breyne'a', in Kolekcje przyrodnicze i gospodarcze innowacje - tradycja i nowoczesność: Pamięci księżnej Anny z Sapiehów Jabłonowskiej (1728-1800), ed. Iwona Arabas and Robert Księżopolski, Warszawa and Ciechanowiec: Aspra, 2021, pp.115-31.

Pękacka-Falkowska, Katarzyna, 'Horti sicci Jacoba Breyne'a z 1659 i 1673 roku', ZH, 83, 2018, 2, pp. 47-83, 〈http://dx.doi.org/10.15762/ZH.2018.23〉.

Pękacka-Falkowska, Katarzyna, 'Johann Philipp Breyne i jego ogrody: hortus vivus i hortus siccus', in Historia - klimat - przyroda: Perspektywa antropocentryczna, ed. Piotr Oliński and Wojciech Piasek, Toruń: Wydawnictwo Naukowe Uniwersytetu Mikołaja Kopernika, 2018, pp. 217-28.

Pękacka-Falkowska, Katarzyna and Bartłomiej Siek, 'Johannes Schmiedt (16231690)', Journal of Neurology, 2021, ahead of print, 〈https://doi.org/10.1007/ s00415-021-10602-w $>$.

Rauschert, Stephan, 'Das Herbarium von Paul Hermann (1646-1695) in der Forschungsbibliothek Gotha', N.F. Hercynia, 7, 1970, 4, pp. 301-28.

Riley, Margaret, 'The Club at the Temple Coffee House Revisited', Archives of Natural History, 33, 2006, 1, pp. 90-100.

Silent Messengers: The Circulation of Material Objects of Knowledge in the Early Modern Low Countries, ed. Sven Dupré and Christoph Lüthy, Münster: Lit Verlag, 2008. The Sloane Herbarium: An Annotated List of the Horti Sicci Composing It; With Biographical Details of the Principal Contributors, Based on Records Compiled by the Late James Britten. With an Introd. by S. Savage, ed. James Edgar Dandy, London: British Museum (Natural History). Department of Botany, 1958.

Stearns, Raymond Phineas, 'James Petiver: Promoter of Natural Science, C. 16631718', Proceedings of American Antiquarian Society, 62, 1952, pp. 243-365.

Targosz, Karolina, Jacob Breynius 1637-1697: 'Botanicus celeberrimus' w wymiarze europejskim, Cracow: PAU, 2010.

van Ooststroom, Simon Jan, 'Een 17de eeuwsch herbarium uit de omgeving van Danzig', in Gedenkboek J. Valckenier Suringar, 24 December 1864-17 October 1932: gewijd aan de nagedachtenis van prof. dr. J. Valkenier Suringar, leeraar aan de voormalige Rijks hoogere land-, tuin- en boschbouwschool en hoogleraar aan de 
Landbouwhoogeschool te Wageningen van 1 april 1899 tot 1 januari 1925, ed. J. Jaswiet, Wageningen: H. Veenman \& Zonen, 1942, pp. 208-17.

Weichbrodt-Tiedemann, Dorothea, Patrizier, Bürger, Einwohner der Freien und Hansestadt Danzig in Stamm- und Nementafeln vom 14.-18. Jahrhundert, 5 vols, Klausdorf bei Kiel: Danziger Verlagsgesellschaft Paul Rosenberg, 1988-93, vol. 1, 1988. Wissen im Netz: Botanik und Pflanzentransfer in europäischen Korrespondenznetzen des 18. Jahrhunderts, ed. Regina Hauser et al., Berlin: Akademie Verlag, 2008.

Biog r a phy: Katarzyna Pękacka-Falkowska, PhD, assistant professor at the Department of History and Philosophy of Medical Sciences, Poznań University of Medical Sciences. Research interests: history of science, particularly of medicine and natural sciences, social history of Polish Prussia; contact: pekackafalkowska@ump.edu.pl. 